I E S E

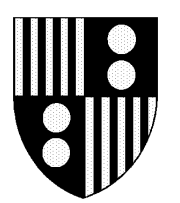

University of Navarra

EQUIVALENCE OF THE APV, WACC AND

FLOWS TO EQUITY APPROACHES

TO FIRM VALUATION

Pablo Fernández*

RESEARCH PAPER No 292

April, 1995

* Professor of Finance

Research Division

\title{
IESE
}

University of Navarra

Av. Pearson, 21

08034 Barcelona - Spain 


\title{
EQUIVALENCE OF THE APV, WACC AND FLOWS TO EQUITY APPROACHES TO FIRM VALUATION (1)
}

\begin{abstract}
This paper shows that the three valuation methods (if used correctly) always yield the same result.
\end{abstract}

The most striking result of this paper is that the Net Present Value of the tax shield due to interest payments (in the APV approach) should be calculated as follows in order to derive an accurate result:

$$
\text { NPV OF INTEREST TAX SHIELDS }=\sum_{t=1}^{\infty} \frac{\mathrm{D}_{\mathrm{t}-1} \mathrm{Ku}_{\mathrm{t}} \mathrm{T}}{\prod_{\mathrm{t}=1}^{\mathrm{t}}\left(1+\mathrm{Ku}_{\mathrm{t}}\right)}
$$

$\mathbf{T}=$ Corporate tax rate

$\mathbf{K} \mathbf{u}_{\mathbf{t}}=$ Cost of unlevered equity in period $\mathbf{t}$

$\mathbf{D}_{\mathbf{t}-\mathbf{1}}=$ Value of debt in period $\mathrm{t}-1$

At first, it would appear that this formula implies that debt has a cost of $\mathrm{Ku}$, and that the interest tax shields are discounted at $\mathrm{Ku}$, but this is not the case. The Net Present Value of interest tax shields is not (and this is the main error in previous papers about this topic) the NPV of a unique flow, but the difference of two NPVs of two flows with different risks: the NPV of the taxes paid in the unlevered firm and the NPV of taxes paid in the levered firm. Our formula is the difference of these two NPVs. Obviously, the flow of taxes paid in the levered firm is smaller but riskier than the flow of taxes paid in the unlevered firm.

We will show that, if used correctly, these three approaches to firm valuation will yield the same result. We will apply these valuation procedures to perpetuities, to growing companies (at a constant rate g) and, finally, to any company.

The main objective of this paper is to show that the three valuation methods (see formulas [1], [2] and [3]) always yield the same result. The paper also helps to think more about the meaning of the formulas and their relationships. 


\section{EQUIVALENCE OF THE APV, WACC AND FLOWS TO EQUITY APPROACHES TO FIRM VALUATION}

\section{Valuation formulas (2)}

\section{Dictionary:}

$\mathbf{T}=$ Corporate tax rate $; \quad \mathbf{F C F}=$ Free cash flow $\quad \quad$ CFacc $=$ available Cash flow for shareholders $(3)$; $\mathbf{I}=$ interest paid; $\quad \mathbf{K}_{\mathbf{u}}=$ Cost of unlevered equity (required return of unlevered equity); $\mathbf{K e}=$ Cost of levered equity (required return of levered equity); $\mathbf{K}_{\mathbf{T u}}=$ Appropriate discount rate for tax flow of unlevered firm; $\mathbf{K d}=$ Required return of debt; $\mathbf{K}_{\mathbf{T}} \mathbf{L}=$ Appropriate discount rate for tax flow of levered firm; $\mathbf{R}_{\mathbf{F}}=$ Risk free rate;

$\mathbf{D}=\mathbf{D}_{\mathbf{0}}=$ Value of debt at $\mathrm{t}=0$; $\mathbf{V}_{\mathbf{U}}=$ Value of shares in the unlevered company at $\mathrm{t}=0$; $\mathbf{r}=$ Cost of debt;

WACC = weighted average cost of capital; $\mathbf{b}_{\mathbf{d}}=$ Beta of debt; $\mathbf{b}_{\mathbf{L}}=$ Beta of levered equity;

Taxes $_{\mathbf{U}}=$ Taxes paid by the unlevered company;

Nominal amount of debt repaid in year $t$; $\mathbf{b}_{\mathbf{U}}=$ Beta of unlevered equity = beta of assets; $\mathbf{P}_{\mathbf{M}}=$ Market premium $=\mathrm{E}\left(\mathrm{R}_{\mathrm{M}}-\mathrm{R}_{\mathrm{F}}\right)$ $\mathbf{G O V}_{\mathbf{U}}=\mathrm{NPV}$ of $\mathbf{T a x e s} \mathbf{U}=$ portion of the value of the unlevered company that belongs to the government $\mathbf{G O V}_{\mathbf{L}}=\mathrm{NPV}$ of TaxesL $=$ portion of the value of the levered company that belongs to the government.

The WACC approach to firm valuation:

[1]

$$
\mathrm{D}+\mathrm{C}=\sum_{\mathrm{t}=1}^{\infty} \frac{\mathrm{FCF}_{\mathrm{t}}}{\prod_{1}^{\mathrm{t}}\left(1+\mathrm{WACC}_{\mathrm{t}}\right)}
$$

The flows to equity approach to equity valuation:

[2]

$$
\mathrm{C}=\sum_{\mathrm{t}=1}^{\infty} \frac{\mathrm{CFacc}_{\mathrm{t}}}{\prod_{1}^{\mathrm{t}}\left(1+\mathrm{Ke}_{\mathrm{t}}\right)}
$$


The APV formula:

[3]

$$
\mathrm{D}+\mathrm{C}=\sum_{\mathrm{t}=1}^{\infty} \frac{\mathrm{FCF}_{\mathrm{t}}}{\prod_{1}^{\mathrm{t}}\left(1+\mathrm{Ku}_{\mathrm{t}}\right)}+\mathrm{NPV} \text { of interest tax shields }
$$

Value of debt (4):

[4]

$$
D_{0}=\sum_{t=1}^{\infty} \frac{I_{t}+N_{t}}{\prod_{1}^{t}\left(1+K_{t}\right)}
$$

From CAPM:

[5] $\mathrm{Ku}=\mathrm{R}_{\mathrm{F}}+\mathrm{b}_{\mathrm{U}} \mathrm{P}_{\mathrm{M}}$

$$
\text { ; [6] } \mathrm{Ke}=\mathrm{R}_{\mathrm{F}}+\mathrm{b}_{\mathrm{L}} \mathrm{P}_{\mathrm{M}} \quad \text {; [7] } \mathrm{Kd}=\mathrm{R}_{\mathrm{F}}+\mathrm{b}_{\mathrm{d}} \mathrm{P}_{\mathrm{M}}
$$

\section{Perpetuities (No growth)}

$[3 p]:$

For perpetuities without growth, [1], [2] and [3] can be written as [1p], [2p] and

[1p $] \mathrm{C}=\mathrm{FCF} / \mathrm{WACC}-\mathrm{D} ; \quad \mathrm{D}=\mathrm{I} / \mathrm{Kd}$

[2p] $\mathrm{C}=\mathrm{CFacc} / \mathrm{Ke}$

[3p] $\quad \mathrm{C}=\mathrm{FCF} / \mathrm{Ku}+\mathrm{NPV}$ of interest tax shields $-\mathrm{D}$

The relationship between FCF and CFacc is:

[4p] $\quad$ CFacc $=$ FCF - I $(1-T)=$ FCF - D Kd $(1-T)$

\subsection{Relationships implied by the valuation formulas}

Because $[1 p]$ and $[2 p]$ must yield the same result, using [4p], we get:

$$
\frac{\text { FCF }}{\text { WACC }}-\mathrm{D}=\frac{\mathrm{FCF}-\mathrm{D} \mathrm{Kd}(1-\mathrm{T})}{\mathrm{Ke}}
$$

Some algebra and we get the definition of WACC:

$[8]$

$$
\mathrm{WACC}=\frac{\mathrm{CKe}+\mathrm{D} \mathrm{Kd}(\mathbf{1}-\mathrm{T})}{\mathrm{C}+\mathrm{D}}
$$


For a perpetuity, profit after tax (PAT) is equal to the available cash-flow for the shareholders (5) (CFacc): PAT $=$ CFacc

$\mathrm{FCF}_{0}$ is the free cash flow of the company without taxes (6): $\mathrm{FCF}=\mathrm{FCF}_{0}(1-\mathrm{T})$. For the unlevered company $(\mathrm{D}=0): \operatorname{Taxes}_{\mathrm{U}}=\mathrm{T} \mathrm{PBT}_{\mathrm{U}}=\mathrm{T} \mathrm{FCF}_{0}$. From this equation it should be clear that the taxes paid by the unlevered company have the same risk as $\mathrm{FCF}_{0}$, and their required rate of return is $\mathrm{Ku}$.

For the levered company: $\operatorname{Taxes}_{\mathrm{L}}=\mathrm{T} \mathrm{PBT}_{\mathrm{L}}=\mathrm{TPAT}_{\mathrm{L}} /(1-\mathrm{T})=\mathrm{T} \mathrm{CFacc} /(1-\mathrm{T})$ From this equation it should be clear that the taxes paid by the levered company have the same risk as CFacc, and their required rate of return is Ke.

The NPV of taxes paid by the levered company, which is the portion of the value of the company that belongs to the government $\left(\mathrm{GOV}_{\mathrm{L}}\right)$ is $(7)$ :

$$
\mathrm{GOV}_{\mathrm{L}}=\mathrm{TPBT} / \mathrm{Ke}=\mathrm{T} \mathrm{PAT}_{\mathrm{L}} /[(1-\mathrm{T}) \mathrm{Ke}]=\mathrm{T} \text { CFacc } /[(1-\mathrm{T}) \mathrm{Ke}]
$$

The NPV of taxes paid by the unlevered company, which is the portion of the value of the unlevered company that belongs to the government $\left(\mathrm{GOV}_{\mathrm{U}}\right)$ is

$$
\mathrm{GOV}_{\mathrm{U}}=\mathrm{T} \text { FCF } /[(1-\mathrm{T}) \mathrm{Ku}]
$$

The NPV of interest tax shield is: $\left.\mathrm{GOV}_{\mathrm{U}}-\mathrm{GOV}_{\mathrm{L}}=[\mathrm{T} / 1-\mathrm{T})\right][\mathrm{FCF} / \mathrm{Ku}-\mathrm{CFacc} / \mathrm{Ke}]$

Using [2p] and [3p]:

\section{[9] NPV of interest tax shield = DT}

As we will see, formula [9] only holds for constant perpetuities (without growth).

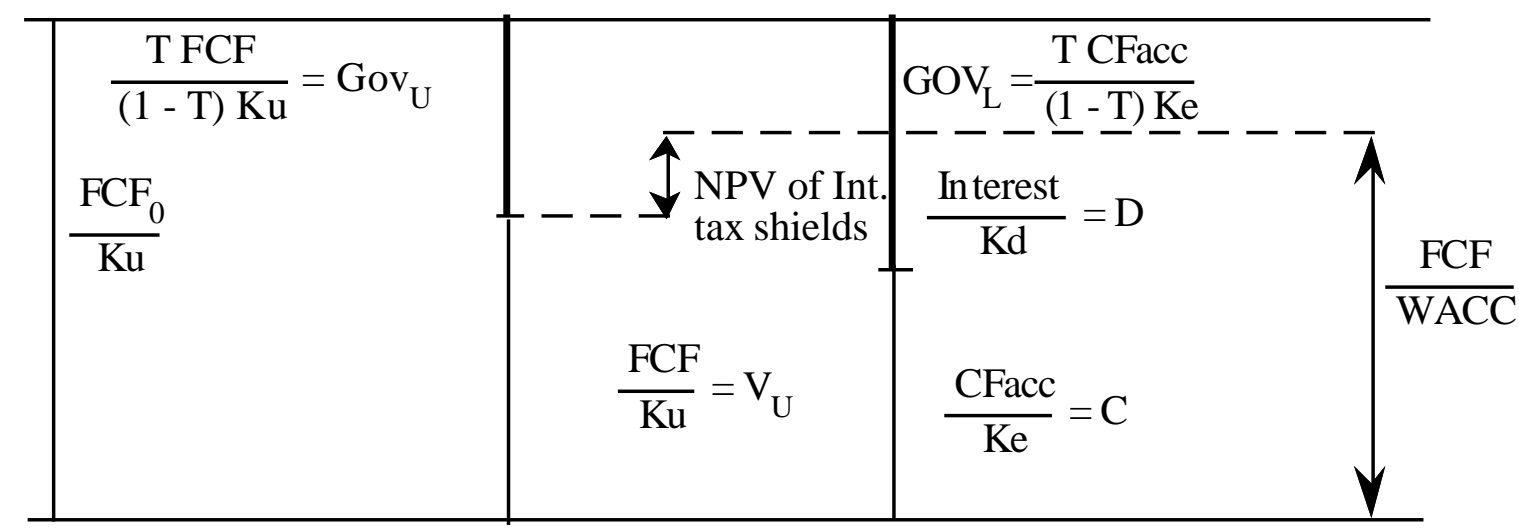
No taxes
$\mathbf{D}=\mathbf{0}$
Levered company
$\mathbf{D}=\mathbf{0}$

Because $[2 p]$ and $[3 p]$ must yield the same result (8), using [4p], we get:

[10]

$$
K u=\frac{C K e+D K d(1-T)}{C+D(1-T)}
$$


From [10], and using [5], [6] and [7], we get

[11]

$$
\beta_{\mathrm{L}}=\frac{\beta_{\mathrm{U}}[\mathrm{C}+\mathrm{D}(1-\mathrm{T})]-\beta_{\mathrm{d}} \mathrm{D}(1-\mathrm{T})}{\mathrm{C}}
$$

Because [1p] and [3p] must yield the same result, we get:

$$
\mathrm{WACC}=K u \frac{C+D(1-T)}{C+D}=K u\left(1-\frac{D T}{C+D}\right)
$$

Formula [12] means that (if T>0) WACC is smaller (9) than $\mathrm{Ku}$.

From [3p] we find another formula to value the equity:

$$
\mathrm{C}=\frac{\mathrm{FCF}}{\mathrm{Ku}}+\mathrm{DT}-\mathrm{D}=\frac{\mathrm{CFacc}+\mathrm{D} \mathrm{Kd}(1-\mathrm{T})}{\mathrm{Ku}}+\frac{\mathrm{D} \mathrm{Ku} \mathrm{T}}{\mathrm{Ku}}-\mathrm{D}
$$

[13]

$$
C=\frac{C F a c c}{K u}-\frac{D(1-T)(K u-K d)}{K u}
$$

[14]

$$
\mathbf{K}_{\mathbf{T}_{\mathbf{u}}}=\mathbf{K}_{\mathbf{u}} ; \quad \mathbf{K}_{\mathbf{T}_{\mathbf{L}}}=\mathbf{K e}
$$

\subsection{Examples of companies without growth}

Table 1 shows the valuation of 4 companies without growth. The four companies have different debt and tax rates. Company 1 is a company without debt and $\mathrm{T}=0$. Company 2 is a company without debt and $\mathrm{T}=35 \%$. Company 3 is a company with debt $=1000$ million and $\mathrm{T}=0$. Company 4 is a company with debt $=1000$ million and $\mathrm{T}=35 \%$. We calculate the value of the equity using the three valuation formulas ( $[1 \mathrm{p}],[2 \mathrm{p}]$ and [3p] ) and we get the same result (see lines 20, 23 and 26). 
Table 1. Perpetuities without growth

\begin{tabular}{|c|c|c|c|c|c|}
\hline & & $\begin{array}{r}\mathrm{D}=0 \\
\mathrm{~T}=0 \% \\
\mathrm{~g}=0 \%\end{array}$ & $\begin{array}{r}\mathrm{D}=0 \\
\mathrm{~T}=35 \% \\
\mathrm{~g}=0 \%\end{array}$ & $\begin{array}{r}\mathrm{D}=1000 \\
\mathbf{T}=\mathbf{0 \%} \\
\mathrm{Kd}=13 \% \\
\mathrm{~g}=0 \%\end{array}$ & $\begin{array}{r}\mathrm{D}=1000 \\
\mathrm{~T}=35 \% \\
\mathrm{Kd}=13 \% \\
\mathrm{~g}=0 \%\end{array}$ \\
\hline & & $\begin{array}{c}\text { Company } 1 \\
{[1]}\end{array}$ & $\underset{[2]}{\text { Company } 2}$ & $\underset{[3]}{\text { Company } 3}$ & $\begin{array}{c}\text { Company } 4 \\
{[4]}\end{array}$ \\
\hline 1 & P.B.I.T. (profit before interest and taxes) & 1000 & 1000 & 1000 & 1000 \\
\hline 2 & Interest & 0 & 0 & 130 & 130 \\
\hline 3 & PBT & 1000 & 1000 & 870 & 870 \\
\hline 4 & Taxes & 0 & 350 & 0 & 304.5 \\
\hline 5 & PAT & 1000 & 650 & 870 & 565.5 \\
\hline 6 & + Depreciation & 200 & 200 & 200 & 200 \\
\hline 7 & - Payment of fixed assets & -200 & -200 & -200 & -200 \\
\hline$\underline{8}$ & CFacc & $\underline{1000}$ & 650 & 870 & 565.5 \\
\hline$\underline{\overline{9}}$ & $\underline{\mathbf{F C F}}$ & $\underline{\overline{1000}}$ & $\overline{650}$ & $\underline{\underline{1000}}$ & $\underline{650}$ \\
\hline 10 & ßu & 1.00 & 1.00 & 1.00 & 1.00 \\
\hline 11 & $\mathrm{Rf}$ & $12.00 \%$ & $12.00 \%$ & $12.00 \%$ & $12.00 \%$ \\
\hline 12 & $\mathrm{E}(\mathrm{Rm}-\mathrm{Rf})=$ market premium & $8.00 \%$ & $8.00 \%$ & $8.00 \%$ & $8.00 \%$ \\
\hline 13 & $\mathrm{Ku}$ & $20.00 \%$ & $20.00 \%$ & $20.00 \%$ & $20.00 \%$ \\
\hline 14 & Vu & 5,000 & 3,250 & 5,000 & 3,250 \\
\hline 15 & $\mathrm{D}$ & 0 & 0 & 1,000 & 1,000 \\
\hline 16 & $\mathrm{Kd}$ & & & $13.00 \%$ & $13.00 \%$ \\
\hline 17 & Beta d (ßd) & & & 0.125 & 0.125 \\
\hline 18 & NPV of interest tax shields $=$ DT & 0 & 0 & 0 & 350 \\
\hline 19 & NPV of interest tax shields $+\mathrm{Vu}$ & 5,000 & 3,250 & 5,000 & 3,600 \\
\hline 20 & $-D=C$ & 5,000 & 3,250 & 4,000 & 2,600 \\
\hline 21 & Beta levered $(\beta \mathrm{L})$ & 1.000000 & 1.000000 & 1.218750 & 1.218750 \\
\hline 22 & $\mathrm{Ke}$ & $20.00 \%$ & $20.00 \%$ & $21.75 \%$ & $21.75 \%$ \\
\hline 23 & $\mathrm{C}=\mathrm{CF} / \mathrm{Ke}$ & 5,000 & 3,250 & 4,000 & 2,600 \\
\hline 24 & WACC & $20.0000 \%$ & $20.0000 \%$ & $20.0000 \%$ & $18.0556 \%$ \\
\hline 25 & FCF / WACC & 5,000 & 3,250 & 5,000 & 3,600 \\
\hline 26 & $\mathbf{C}=(\mathrm{FCF} / \mathrm{WACC})-\mathrm{D}$ & 5,000 & 3,250 & 4,000 & 2,600 \\
\hline 27 & Value of EQUITY (C) & 5,000 & 3,250 & 4,000 & 2,600 \\
\hline 28 & Value of DEBT (D) & $\mathbf{0}$ & $\mathbf{0}$ & 1,000 & 1,000 \\
\hline 29 & NPV of taxes (GOV) & $\mathbf{0}$ & 1,750 & $\mathbf{0}$ & 1,400 \\
\hline 30 & SUM $(27+28+29)$ & 5,000 & 5,000 & 5,000 & 5,000 \\
\hline 31 & FCFo & 1,000 & 1,000 & 1,000 & 1,000 \\
\hline
\end{tabular}

Lines 1 to 5 show the P\&L of the four companies. Line 8 shows the available cash flow for shareholders (CFacc).

Line 9 shows the Free Cash Flow (FCF). Line 10. We assume the unlevered beta $=\beta u=1$. Line 11. We assume the risk-free rate $=R F=12 \%$. Line 12. Market premium $=E(R m-R F)=8 \%$. Line 13. Cost of unlevered equity $=K u=R F+B u E(R m-$ $\mathrm{Rf})=20 \%$. Line 14. Value of unlevered company $(\mathrm{Vu}=\mathrm{FCF} / \mathrm{Ku})=5,000$ millions when $\mathrm{T}=0$ and 3,250 millions when $\mathrm{T}=35 \%$. Line 15. Value of debt. Line 16 is the cost of debt (Kd). Line 17. Beta that corresponds to debt according to [7]. Line 18. NPV of interest tax shields, which for these companies (perpetuities without growth) is DT. Lines 19 and 20. Use of formula [3p]. Line 21. Leveraged beta according to formula [11]. Line 22. Required return of leveraged equity according to [6]. Line 23. Value of equity according to formula [2p]. Line 24. WACC according to formula [8]. Lines 25 and 26. Value of equity according to formula [1p]. 


\section{Companies with constant growth}

For companies growing at a constant rate g, formulas [1], [2] and [3] can be written as $[1 \mathrm{c}],[2 \mathrm{c}]$ and $[3 \mathrm{c}]$ :

[1c] $\quad \mathrm{C}=\frac{\mathrm{FCF}_{1}}{\mathrm{WACC}-\mathrm{g}}-\mathrm{D}$

[2c] $\quad \mathrm{C}=\frac{\mathrm{CFacc}_{1}}{\mathrm{Ke}-\mathrm{g}}$

[3c] $\quad \mathrm{C}=\frac{\mathrm{FCF}_{1}}{\mathrm{~K}_{\mathrm{u}}-\mathrm{g}}+\mathrm{NPV}$ of interest tax shields-D

The relationship between FCF and CFacc:

$[4 c]$

$$
\begin{aligned}
& \text { CFacc }=F C F-I(1-T)+\Delta D ; \quad \text { as I }=\mathrm{D} \mathrm{Kd} ; \quad \text { and } \quad \Delta \mathrm{D}=\mathrm{g} \mathrm{D}, \\
& \mathrm{CFacc}_{1}=\mathrm{FCF}_{1}-\mathrm{Do}[\mathrm{Kd}(1-\mathrm{T})-\mathrm{g}]
\end{aligned}
$$

\subsection{Relationships implied by the valuation formulas}

Because [1c] and [2c] must yield the same result, using [4c], we find again formula [8]:

[8] $\quad \mathrm{WACC}=\frac{\mathrm{C} \mathrm{Ke}+\mathrm{D} \mathrm{Kd}(1-\mathrm{T})}{\mathrm{C}+\mathrm{D}}$

Because [1c] and [3c] must yield the same result, we get:

$(\mathrm{C}+\mathrm{D})(\mathrm{WACC}-\mathrm{g})=(\mathrm{C}+\mathrm{D}-\mathrm{NPVint}$ tax shields $)(\mathrm{Ku}-\mathrm{g}) \quad$ then:

[15] NPV interest tax shields $=(\mathrm{C}+\mathrm{D})(\mathrm{Ku}-\mathrm{WACC}) /(\mathrm{Ku}-\mathrm{g})$

$\mathrm{FCF}_{0}$ is the free cash flow of the company without taxes.

By definition: $\mathrm{FCF}_{0}=\mathrm{FCF}+$ Taxes $_{\mathrm{U}}$

Taxes $_{U}$ are the taxes paid by the unlevered company $(\mathrm{D}=0): \operatorname{Taxes}_{\mathrm{U}}=\mathrm{T} \mathrm{PBT}_{\mathrm{U}}$

For constant growth companies (10), $\mathrm{PBT}_{\mathrm{U}} \neq \mathrm{FCF0}$. We define a parameter $\mathrm{H}$ that takes into account this difference (normally due to increases in working capital requirements and net fixed assets): $\mathrm{PBT}_{\mathrm{U}}=\mathrm{FCF}_{0}+\mathrm{H}$. Then: Taxes $_{\mathrm{U}}=\mathrm{T}\left(\mathrm{FCF}_{0}+\mathrm{H}\right)$. And also (11):

$\mathrm{FCF}_{0}=(\mathrm{FCF}+\mathrm{T} \mathrm{H}) /(1-\mathrm{T})$.

For the levered company:

Taxes $_{\mathrm{L}}=\left[\mathrm{FCF}_{0}+\mathrm{H}-\mathrm{Kd} \mathrm{D}\right] \mathrm{T}$

It is clear that the taxes paid by the levered company do not have the same risk as CFacc. 
The NPV of taxes paid by the unlevered company, which is the portion of the value of the unlevered company that belongs to the government $\left(\mathrm{GOV}_{\mathrm{U}}\right)$, is

$\mathrm{GOV}_{\mathrm{U}}=\operatorname{Taxes}_{\mathrm{U}} /(\mathrm{Ku}-\mathrm{g})=\mathrm{T}(\mathrm{FCF} 0+\mathrm{H}) /(\mathrm{Ku}-\mathrm{g})$

The NPV of taxes paid by the levered company, which is the portion of the value of the company that belongs to the government $\left(\mathrm{GOV}_{\mathrm{L}}\right)$, is $(12)$ :

$\mathrm{GOV}_{\mathrm{L}}=\operatorname{Taxes}_{\mathrm{L}} /\left(\mathrm{K}_{\mathrm{T}}-\mathrm{g}\right)=\left(\mathrm{FCF}_{0}+\mathrm{H}-\mathrm{Kd} \mathrm{D}\right) \mathrm{T} /\left(\mathrm{K}_{\mathrm{T}_{\mathrm{L}}}-\mathrm{g}\right)$

The NPV of the interest tax shield is:

$$
\begin{aligned}
\mathrm{GOV}_{\mathrm{U}}-\mathrm{GOV}_{\mathrm{L}} & =\left[\mathrm{T}\left(\mathrm{FCF}_{0}+\mathrm{H}\right) /(\mathrm{Ku}-\mathrm{g})\right]-\left[\mathrm{T}\left(\mathrm{FCF}_{0}+\mathrm{H}-\mathrm{Kd} \mathrm{D}\right) /\left(\mathrm{K}_{\mathrm{TL}}-\mathrm{g}\right)\right]= \\
& =[\mathrm{T} /(1-\mathrm{T})]\left[[(\mathrm{FCF}+\mathrm{H}) /(\mathrm{Ku}-\mathrm{g})]-\left[(\mathrm{CFacc}+\mathrm{H}-\mathrm{gD}) /\left(\mathrm{K}_{\mathrm{T}}-\mathrm{g}\right)\right]\right]
\end{aligned}
$$

Taking into account [10] and [15], we find [16] and [17]:

$$
\begin{aligned}
& (\mathrm{C}+\mathrm{D})(\mathrm{Ku}-\mathrm{g})-\mathrm{DT} \mathrm{Ku}=\mathrm{C}(\mathrm{Ke}-\mathrm{g})+\mathrm{D}[\mathrm{Kd}(1-\mathrm{T})-\mathrm{g}], \\
& \text { NPV of interest tax shields }=\frac{\mathrm{C}+\mathrm{D}}{\mathrm{Ku}-\mathrm{g}}\left[\mathrm{Ku}-\mathrm{Ku} \frac{\mathrm{C}+\mathrm{D}(1-\mathrm{T})}{\mathrm{C}+\mathrm{D}}\right]=\frac{\mathrm{DTKu}}{\mathrm{Ku}-\mathrm{g}}
\end{aligned}
$$

\section{[16] NPV of interest tax shields $=$ DT Ku $/(\mathrm{Ku}-\mathrm{g})$}

At first, it would appear that this formula implies that debt has a cost of $\mathrm{Ku}$, and that the interest tax shields are discounted at $\mathrm{Ku}$, but this is not the case (13). The NPV of interest tax shields is not (and this is the main error in previous papers on this topic) the NPV of a unique flow, but the difference of two NPVs of two flows with different risk: the NPV of the taxes paid in the unlevered firm and the NPV of taxes paid in the levered firm. Our formula is the difference of the two NPV. Obviously, the flow of taxes paid by the levered firm is smaller, but riskier than the flow of taxes paid by the unlevered firm.

[17]

$$
\mathrm{K}_{\mathrm{T}_{\mathrm{L}}}-\mathrm{g}=\frac{\mathrm{CKe}-\mathrm{g}(\mathrm{C}+\mathrm{D})+\mathrm{H}}{\mathrm{CKu}-\mathrm{g}(\mathrm{C}+\mathrm{D})+\mathrm{H}}(\mathrm{Ku}-\mathrm{g})
$$

[17] can also be written as (14):

$$
\mathrm{K}_{\mathrm{T}_{\mathrm{L}}}=\mathrm{Ku}+\frac{\mathrm{D}(1-\mathrm{T})(\mathrm{Ku}-\mathrm{Kd})}{\mathrm{C}+\frac{\mathrm{H}-\mathrm{gD}}{\mathrm{Ku}-\mathrm{g}}}
$$

Comparing [17] with [10], it is clear that $\mathrm{K}_{\mathrm{T}_{\mathrm{L}}}>\mathrm{Ke}$ when $\mathrm{H}<\mathrm{g} \mathrm{D}$, and $\mathrm{K}_{\mathrm{T}}<\mathrm{Ke}$ when $\mathrm{H}>\mathrm{g} \mathrm{D}$.

In Exhibits 1, 2, 3 and 4, the difference between PBT and FCF is only due to the increase in working capital requirements: $\mathrm{H}=\mathrm{g}$ WCR. In Exhibit $1^{* *}$, the difference is also due to increases in net fixed assets: $\mathrm{H}=\mathrm{g}$ (WCR $+\mathrm{NFA})$. 
Because [2c] and [3c] must yield the same result, using [4p], we get:

$(\mathrm{C}+\mathrm{D}) \mathrm{Ku}-\mathrm{DT} \mathrm{Ku}=\mathrm{C} \mathrm{Ke}+\mathrm{D} \mathrm{Kd}(1-\mathrm{T})$,

Value of the company that corresponds to shares (C), debt (D) and government (GOV) in three different scenarios.

We consider that FCF and FCFo have the same risk

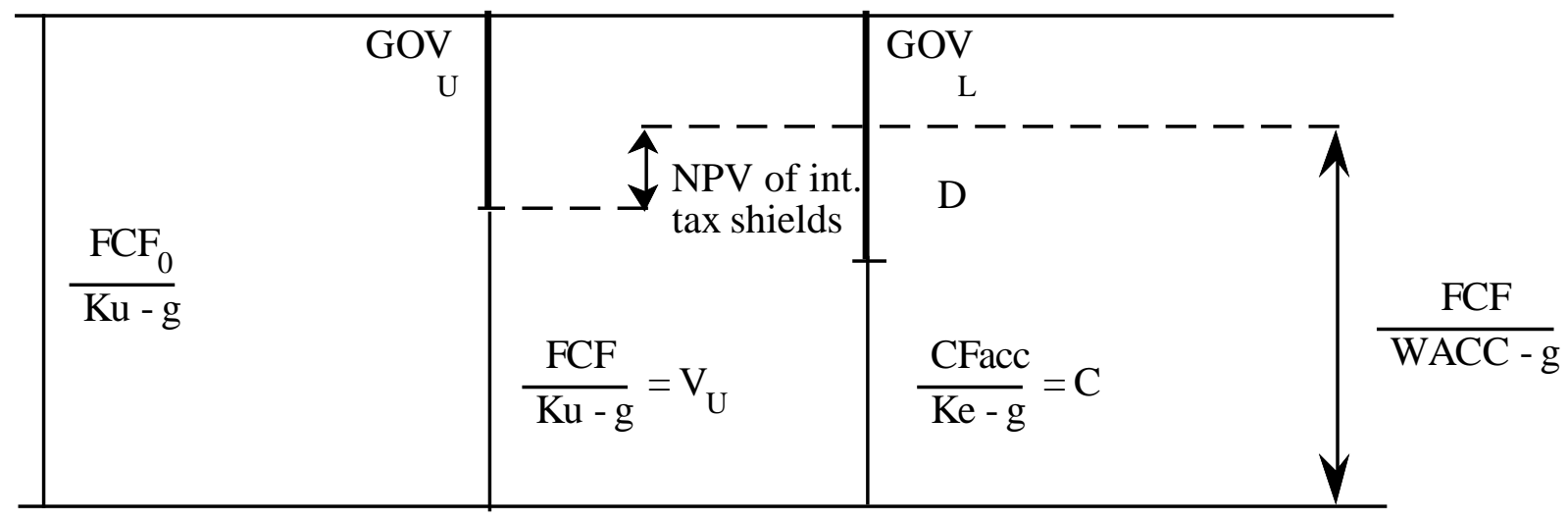

$\mathrm{D}=\mathbf{D}=\mathbf{0} \quad$ Levered company

$\mathbf{T}=\mathbf{0}$

From [3c], using [15] and [4c], we get [18], which is an alternative formula (a kind of certainty equivalent) to [2c]: this provides a way to value the equity without calculating $\mathrm{Ke}$.

$$
C=\frac{F C F}{K u-g}+\frac{D K u T}{K u-g}-D=\frac{C F a c c+D K d(1-T)-g D+D K u T-D K u+g ~ D}{K u-g}
$$

[18]

$$
\mathrm{C}=\frac{\mathrm{CFacc}}{\mathrm{Ku}-\mathrm{g}}-\frac{\mathrm{D}(\mathrm{Ku}-\mathrm{Kd})(1-\mathrm{T})}{\mathrm{Ku}-\mathrm{g}}
$$

The «maximum theoretical debt» that the company can support, that is, debt when $\mathrm{C}=0$, is (when $\mathrm{CFacc}=0)(15)$ :

$$
\mathrm{D}_{0}=\frac{\mathrm{FCF}}{\mathrm{Kd}(1-\mathrm{T})-\mathrm{g}}
$$

In this situation, as [18] holds, $\mathrm{Kd}=\mathrm{Ku}$, then from [4c]:

$$
\mathrm{D}_{0}=\frac{\mathrm{FCF}_{1}}{\mathrm{Ku}(1-\mathrm{T})-\mathrm{g}}=\frac{\mathrm{V}_{\mathrm{U}}(\mathrm{Ku}-\mathrm{g})}{\mathrm{Ku}(1-\mathrm{T})-\mathrm{g}}
$$




\subsection{Examples of companies with constant growth}

Exhibits $1,1^{* *}, 2,3$ and 4 show the valuation of five different companies with constant growth of 5\%. Exhibit $1 * *$ differs from Exhibit 1 only in net fixed assets: Exhibit 1 has constant net fixed assets (as do Exhibits 2, 3 and 4), but in Exhibit $1^{* *}$ net fixed assets also grow 5\%. The companies all have different Debt and Tax rates. Exhibits 1 and continuation show two companies with an initial Debt $=500$ and $\mathrm{T}=35 \%$. Exhibit 2 shows a company with an initial Debt $=500$ and $\mathrm{T}=0$ (no taxes). Exhibit 3 shows an unlevered company (no debt) with $\mathrm{T}=0$. Exhibit 4 shows an unlevered company (no debt) with $\mathrm{T}=35 \%$. We calculate the value of the equity using the three valuation formulas ( [1c], [2c] and [3c] ) and we get the same result (see lines 53, 56 and 61). Table 2 shows some of the results of these five exhibits and provides explanations of the lines.

Table 2. Cash-flows, discount rates and values of companies with constant growth $(\mathrm{g}=\mathbf{5 \%})$ Numbers come from Exhibits 1 to 4

Exhibits that correspond to these values

\begin{tabular}{|c|c|c|c|c|c|}
\hline & [3] & [2] & [4] & [1] & {$[1 * *]$} \\
\hline \multicolumn{6}{|l|}{ Cash-flows of year 1} \\
\hline CFacc (line 27) & 1,000 & 950 & 632.5 & 608.75 & 558.75 \\
\hline Taxes (line 21) & - & - & 367.5 & 341.25 & 341.25 \\
\hline Debt flow (D Kd - $\Delta \mathrm{D})($ line 19 - line 24$)$ & - & 50 & - & 50 & 50 \\
\hline SUM = FCFo (line 43) & 1,000 & 1,000 & 1,000 & 1,000 & 950 \\
\hline Ke (line 55) & $20 \%$ & $20.405 \%$ & $20 \%$ & $20.411 \%$ & $20.45 \%$ \\
\hline Kd (line & - & $15 \%$ & - & $15 \%$ & $15 \%$ \\
\hline KTax & - & - & $20 \%$ & $20.395 \%$ & $20.395 \%$ \\
\hline \multicolumn{6}{|c|}{ Value of Shares (C), Debt (D) and NPV of taxes paid (GOV) in $t=0$} \\
\hline C (lines 53, 56 and 61) & 6,667 & 6,167 & 4,217 & 3,950 & 3,617 \\
\hline GOV $=$ Taxes $/($ KTax-g) & - & - & 2,450 & 2,217 & 2,217 \\
\hline $\mathrm{D}=$ Debt flow/(Kd-g) (line 48) & - & 500 & - & 500 & 500 \\
\hline SUM (lines 44 and 47) & 6,667 & 6,667 & 6,667 & 6,667 & 6,334 \\
\hline \multicolumn{6}{|c|}{ Two ways of calculating the NPV of interest tax shields in $t=0$ : } \\
\hline Correct: DTKu/(Ku-g) (line 51) & & & & 233.33 & 233.33 \\
\hline Wrong: DTKd/(Kd-g) (line 62) & & & & 262.50 & 262.50 \\
\hline
\end{tabular}

Notes to Exhibits 1, 1**, 2, 3 and 4

Lines 1 to 7 show the Assets of the companies. Lines 8 to 11 show the Liabilities and Net Worth of the companies. Line 12 shows the Working Capital Requirements (WCR). Lines 14 to 22: P\&L of the companies. Lines 23 to 27 : available cash flow for shareholders (CFacc). Line $\mathbf{2 8}$ shows the Free Cash Flow (FCF). Line 37. We assume the unlevered beta $=B u=1$. Line 38. We assume the risk free rate $=R_{F}=12 \%$. Line 39. Market premium $=E\left(R_{m^{-}}\right.$ $\left.R_{F}\right)=8 \%$. Line 40. Cost of unlevered equity $=K u=R_{F}+\beta_{u} E(R m-R f)=20 \%$. Line 41. Value of unlevered company $[\mathrm{Vu}=\mathrm{FCF} /(\mathrm{Ku}-\mathrm{g})]$. Line 43 shows the Free cash flow of the company without taxes (FCFo). Line 44. Value of unlevered company without taxes $[\mathrm{Vu}=\mathrm{FCFo} /(\mathrm{Ku}-\mathrm{g})]$. Line 45: Taxes paid by the unlevered company $\left(\right.$ Taxes $\left._{\mathrm{u}}\right)$. Line 46: NPV of Taxes paid by the unlevered company $\left(\mathrm{GOV}_{\mathrm{u}}\right)$. Line 47: $\mathrm{GOV}_{\mathrm{u}}+\mathrm{Vu}$ (line $46+$ line 41 = line 44). Line 48. Value of debt. Line 49 is the cost of debt $(\mathrm{Kd})$. Line 50. Beta that corresponds to debt according to [7]. Line 51. NPV of interest tax shields $=$ DTKu/(Ku-g). Lines 52 and 53. Value of equity according to APV, using formula [3c]. Line 54. Leveraged beta according to formula [11]. Line 55. Required return of leveraged equity according to [6]. Line 56. Value of equity according to formula [2c]. Line 59. WACC according to formula [8]. Lines 60 and 61 . Value of equity according to formula [1c]. Line $\mathbf{6 2}=$ «traditional way» of calculating NPV of interest tax shields $=\mathrm{DTKd} /(\mathrm{Kd}-\mathrm{g})$. 


\section{General case}

\subsection{Relationships implied by the formulas}

We can rewrite [1], [2] and [3] as

[1*] $\quad \mathrm{D}_{1}+\mathrm{C}_{1}=\left(\mathrm{D}_{0}+\mathrm{C}_{0}\right)\left(1+\mathrm{WACC}_{1}\right)-\mathrm{FCF}_{1}$

[2*] $\quad \mathrm{C}_{1}=\mathrm{C}_{0}\left(1+\mathrm{Ke}_{1}\right)-\mathrm{CFacc}_{1}$

[3*] $\quad \mathrm{D}_{1}+\mathrm{C}_{1}=\left(\mathrm{D}_{0}+\mathrm{C}_{0}\right)\left(1+\mathrm{Ku}_{1}\right)-\mathrm{FCF}_{1}-\mathrm{D}_{0} \mathrm{Ku}_{1} \mathrm{~T}$

The relationship between $\mathrm{CFacc}$ and FCF is:

[4*] $\quad \mathrm{CFacc}_{1}=\mathrm{FCF}_{1}+\mathrm{D}_{1}-\mathrm{D}_{0}-\mathrm{D}_{0} \mathrm{Kd}_{1}(1-\mathrm{T})$

From $\left[1^{*}\right],\left[2^{*}\right],\left[3^{*}\right]$ and $\left[4^{*}\right]$, and following the same procedure as in previous sections, we also get:

$$
\begin{array}{lr}
\mathrm{C}_{0} \mathrm{Ke}_{1}+\mathrm{D}_{0} \mathrm{Kd}_{1}(1-\mathrm{T})=\left(\mathrm{D}_{0}+\mathrm{C}_{0}\right) \mathrm{WACC}_{1}, & \text { equivalent to [8] } \\
\mathrm{C}_{0} \mathrm{Ke}_{1}+\mathrm{D}_{0} \mathrm{Kd}_{1}(1-\mathrm{T})=\left[\mathrm{C}_{0}+\mathrm{D}_{0}(1-\mathrm{T})\right] \mathrm{Ku}_{1}, & \text { equivalent to [9] } \\
{\left[\mathrm{C}_{0}+\mathrm{D}_{0}(1-\mathrm{T})\right] \mathrm{Ku}_{1}=\left(\mathrm{D}_{0}+\mathrm{C}_{0}\right) \mathrm{WACC}_{1},} & \text { equivalent to [12] }
\end{array}
$$

and the most noticeable:

[20]

$$
\text { NPV OF INTEREST TAX SHIELDS }=\sum_{t=1}^{\infty} \frac{D_{t-1} K u_{t} T}{\prod_{t=1}^{t}\left(1+K u_{t}\right)}
$$

The following relationships are also important:

$\mathrm{K}_{\mathrm{TU}}=\mathrm{Ku}$

$\mathrm{CFacc}_{\mathrm{t}}=\mathrm{FCF}_{\mathrm{t}}+\Delta \mathrm{D}_{\mathrm{t}}-\mathrm{I}_{\mathrm{t}}(1-\mathrm{T})$

$\Delta \mathrm{D}_{\mathrm{t}}=\mathrm{D}_{\mathrm{t}}-\mathrm{D}_{\mathrm{t}}-1$

$\mathrm{I}_{\mathrm{t}}=\mathrm{D}_{\mathrm{t}}-1 \mathrm{Kd}_{\mathrm{t}}$

$\mathrm{KT}_{\mathrm{L}_{1}}=$ required rate for the Taxes $\mathrm{L}_{1}=\mathrm{Ku}_{1}+\mathrm{T} \mathrm{D}_{0}\left(\mathrm{Ku}_{1}-\mathrm{Kd}_{1}\right) / \mathrm{GOV}_{\mathrm{L}_{0}}$

\subsection{An example of valuation}

Exhibit 5 shows the valuation of a company (16) that grows (but the pattern of growth is not constant) until year 9 . After year 10, we assume a constant growth rate of $5 \%$. 
We calculate the value of the equity using the three valuation formulas ([1], [2] and [3]) and we find the same result (see lines 53, 56 and 61): 506 million in $t=0$.

The most important results of Exhibit 5 are:

1) We get the same value of equity (in $\mathrm{t}=0$ and in future years) using the valuation formulas [1], [2] and [3] (see lines 53, 56 and 61): 506 million.

2) The net present value of interest tax shields (using [20]) is 626.72 million (line 51).

3) If we calculate the net present value of the interest tax shields as the NPV of D $\mathrm{Kd} \mathrm{T}$ discounted at $\mathrm{Kd}$ (see line 62), we obtain a different value: 621.93 million. This therefore leads to a different value from formula [3] in comparison with formulas [1] and [2].

Table 3 shows the most important results of Exhibit 5.

Table 3. Cash-flows, discount rates and values of the company analyzed in Exhibit 5

\begin{tabular}{|c|c|c|c|c|c|c|c|c|c|c|c|c|c|}
\hline Year & $\mathbf{0}$ & 1 & 2 & 3 & 4 & 5 & 6 & 7 & 8 & 9 & 10 & 11 & 12 \\
\hline CFacc (line 27) & & 87 & 19.5 & 20.75 & 38.25 & 25.13 & 35 & 31.65 & 78.65 & 171.02 & 463.42 & 486.59 & 510.92 \\
\hline FCF (line 28) & & 262.5 & -305 & 245 & 512.5 & 475 & 310.5 & 447.4 & 470.02 & 488.02 & 510.92 & 536.47 & 563.29 \\
\hline D (line 9) & 1800 & 1800 & 2300 & 2300 & 2050 & 1800 & 1700 & 1450 & 1200 & 1000 & 1050 & 1102.5 & 1157.63 \\
\hline Kd (line 49) & $15 \%$ & $15 \%$ & $15 \%$ & $15 \%$ & $15 \%$ & $15 \%$ & $15 \%$ & $15 \%$ & $15 \%$ & $15 \%$ & $15 \%$ & $15 \%$ & $15 \%$ \\
\hline $\mathbf{C}($ lines $53,56,57$ and 61) & 506 & 579 & 734 & 935 & 1158 & 1431 & 1741 & 2113 & 2504 & 2873 & 3016 & 3167 & 3326 \\
\hline Net Worth (line 10) & 500 & 530 & 660 & 740 & 770 & 1000 & 1290 & 1610 & 1930 & 2209 & 2243 & 2280 & 231 \\
\hline Bu Beta unlevered (line 37) & 1.00 & 1.00 & 1.00 & 1.00 & 1.00 & 1.00 & 1.00 & 1.00 & 1.00 & 1.00 & 1.00 & 1.00 & $1 .($ \\
\hline BL Beta levered (line 54) & 2.44 & 2.26 & 2.27 & 2.00 & 1.72 & 1.51 & 1.40 & 1.28 & 1.19 & 1.14 & 1.14 & 1.14 & 1. \\
\hline Ku (line 40) & $20 \%$ & $20 \%$ & $20 \%$ & $20 \%$ & $20 \%$ & $20 \%$ & $20 \%$ & $20 \%$ & $20 \%$ & $20 \%$ & $20 \%$ & $20 \%$ & 20 \\
\hline Ke (line 55) & $31.55 \%$ & $30.10 \%$ & $18 \%$ & $3.00 \%$ & $5.75 \%$ & $1.09 \% 2$ & $3.17 \% 2$ & $2.23 \%$ & $21.56 \%$ & $21.13 \%$ & $21.13 \%$ & $21.13 \%$ & 21.13 \\
\hline
\end{tabular}

Unlevered company without taxes:

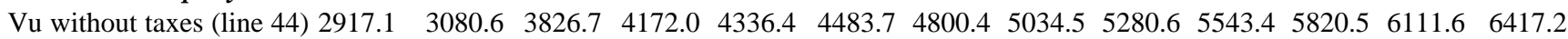

Unlevered company with taxes $=35 \%$ :

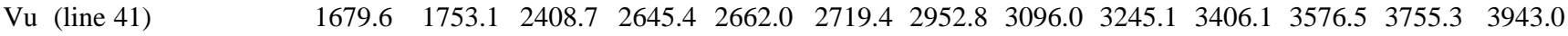

$\begin{array}{llllllllllllll}\text { GOVu (line 42) } & 1237.5 & 1327.5 & 1418.0 & 1526.6 & 1674.4 & 1764.3 & 1847.6 & 1938.5 & 2035.5 & 2137.3 & 2244.0 & 2356.3 & 2474.2\end{array}$

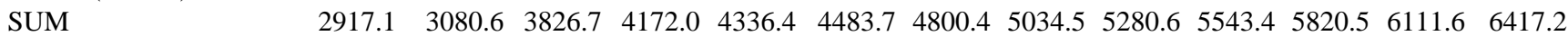

Levered company with taxes $=35 \%$ :

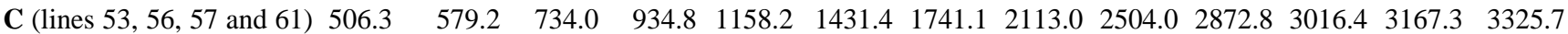

$\begin{array}{llllllllllllll}\text { D (line 9) } & 1800.0 & 1800.0 & 2300.0 & 2300.0 & 2050.0 & 1800.0 & 1700.0 & 1450.0 & 1200.0 & 1000.0 & 1050.0 & 1102.5 & 1157.6\end{array}$

$\begin{array}{llllllllllllll}\text { GOV }_{\mathrm{L}} \text { (line 58) } & 610.8 & 701.4 & 792.7 & 937.2 & 1128.2 & 1252.3 & 1359.3 & 1471.5 & 1576.6 & 1670.6 & 1754.1 & 1841.8 & 1933.9\end{array}$

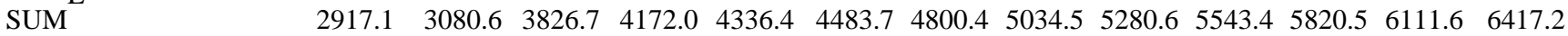


Table 4 shows a sensitivity analysis for the value of the shares $(C)$ when $t=0$.

Table 4. Sensitivity analysis for the value of the shares $(C)$ in $t=0$ Value of the shares $(C)$ in $t=0$, changing one assumption in Exhibit 5

$\begin{array}{ll}\text { Value of shares from Exhibit } \mathbf{5} & \mathbf{5 0 6} \text { millions } \\ \text { Tax rate }=30 \%(\text { instead of 35\%) } & 594 \\ \text { Risk-free rate }(\mathrm{RF})=11 \%(\text { instead of } 12 \%) & 653 \\ \text { Risk premium }(\mathrm{PM})=7 \%(\text { instead of } 8 \%) & 653 \\ \text { bu }=0.9 \text { (instead of } 1.0) & 622 \\ \text { Terminal growth }(\text { after year 10) }=6 \%(\text { instead of 5\%) } & 546\end{array}$

\section{Formulas when the nominal value of $\operatorname{debt}(\mathrm{n})$ is not equal to the «market value» (D)}

In previous sections we have assumed that $r=K d$, but if $r \neq K d$ then the value of debt (D) will be different from its nominal amount (N).

$\mathbf{N}$ is the nominal value of debt (the money that the company has received), $\mathbf{r}$ is the interest rate paid and $\mathbf{N r}$ the annual interest paid.

Kd is the required return of the debt: the «reasonable» rate that would be required by the bondholders or the bank (depending on the business risk and the amount of the debt) (17) if they had the same information that the shareholders have and if they did not expect any agency costs.

\subsection{Perpetuities}

For perpetuities, $\mathbf{N r}=\mathbf{D K d}$, and it can be shown that formulas [1p], [2p], [3p] and [4p] hold. We only need to take into account that $\mathbf{D}=\mathbf{N r} / \mathbf{K d}$.

It is obvious that $[4 \mathrm{p}]$ holds:

$$
[4 \mathrm{p}] \quad \mathrm{CFacc}=\mathrm{FCF}-\mathrm{Nr}(1-\mathrm{T})=\mathrm{FCF}-\mathrm{D} \mathrm{Kd}(1-\mathrm{T})
$$

\subsection{Companies with constant growth}

For companies with constant growth g:

$$
\mathbf{D}=\frac{\mathbf{r} \mathbf{N}-\mathbf{g ~ N}}{\mathrm{Kd}-\mathbf{g}}=\mathbf{N} \frac{\mathbf{r}-\mathbf{g}}{\mathrm{Kd}-\mathbf{g}}
$$

$\mathrm{D} \mathrm{Kd}-\mathrm{Nr}=\mathrm{g}(\mathrm{D}-\mathrm{N})$ if debt grows (the net revenues from banks or bond issues) in year 1 $\Delta \mathrm{N}_{1}=\mathrm{g} \mathrm{N}_{0}$. 
For these companies, we have to introduce some changes in the equations that we developed in the previous sections because

$\left[4 c^{\prime}\right] \quad \mathrm{CFacc}=\mathrm{FCF}-\mathrm{Nr}(1-\mathrm{T})+\mathrm{gN}=\mathrm{FCF}-\mathrm{D}(\mathrm{Kd}-\mathrm{g})+\mathrm{NrT}$

It is clear that if $r \neq \mathrm{Kd}$, then [4c'] is different from [4c].

Substituting [4c'] and [2c] in [1c], we get a new formulation of WACC:

$$
\mathrm{C}+\mathrm{D}=\frac{\mathrm{CFacc}+\mathrm{D}(\mathrm{Kd}-\mathrm{g})-\mathrm{NrT}}{\text { WACC }-\mathrm{g}}=\frac{\mathrm{C}(\mathrm{Ke}-\mathrm{g})+\mathrm{D}(\mathrm{Kd}-\mathrm{g})-\mathrm{NrT}}{\text { WACC }-\mathrm{g}}
$$

[8']

$$
\mathrm{WACC}=\frac{\mathrm{C} \mathrm{Ke}+\mathrm{D} \mathrm{Kd}-\mathrm{Nr} \mathrm{T}}{\mathrm{C}+\mathrm{D}}
$$

Note that formula [8'] is equal to formula [8] when $\mathrm{N}=\mathrm{D}$, which means $\mathrm{r}=\mathrm{Kd}$.

As a result of these changes, formula [16] will also change to [16']. Formula [16'] is equal to formula [16] when $\mathrm{N}=\mathrm{D}$, which means $\mathrm{r}=\mathrm{Kd}$.

[16']

$$
\text { NPV of interest tax shields }=\frac{\mathrm{DTKu}+\mathrm{T}[\mathrm{Nr}-\mathrm{D} \mathrm{Kd}]}{\mathrm{Ku}-\mathrm{g}}
$$

Some other interesting formulas are:

$$
\Delta \mathrm{D}-\Delta \mathrm{N}=\mathrm{g} \mathrm{D}\left[1-\frac{\mathrm{Kd}-\mathrm{g}}{\mathrm{r}-\mathrm{g}}\right]=\mathrm{g} \mathrm{D}\left[\frac{\mathrm{r}-\mathrm{Kd}}{\mathrm{r}-\mathrm{g}}\right]
$$

$\left[16^{\prime \prime}\right] \quad \mathrm{NPV}$ of interest tax shields $=\frac{\mathrm{DTKu}}{\mathrm{Ku}-\mathrm{g}}-\frac{\mathrm{Tg}(\mathrm{D}-\mathrm{N})}{\mathrm{Ku}-\mathrm{g}}$ 
Figure 1. Difference of two companies: one with $\mathbf{r}>\mathrm{Kd}$; the other with $\mathbf{r}=\mathrm{Kd}$.

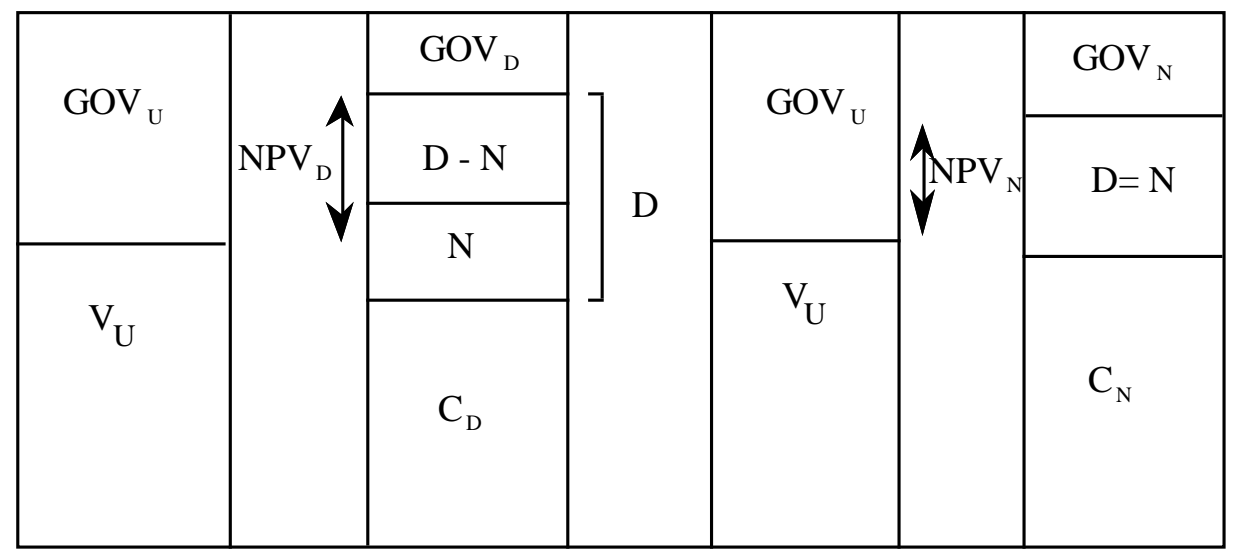

Company with $D>N$ $\mathrm{r}>\mathrm{Kd}$; D > N
Company with $D=N$

$\mathrm{r}=\mathrm{Kd} ; \mathrm{D}=\mathrm{N}$

Figure 1 allows us to write the following identities:

$$
\begin{gathered}
\mathrm{C}_{\mathrm{D}}+\mathrm{D}+\mathrm{GOV}_{\mathrm{D}}=\mathrm{C}_{\mathrm{N}}+\mathrm{N}+\mathrm{GOV}_{\mathrm{N}} ; \\
\mathrm{NPV}_{\mathrm{D}}-\mathrm{NPV}_{\mathrm{N}}=\mathrm{GOV}_{\mathrm{N}}-\mathrm{GOV}_{\mathrm{D}} ;
\end{gathered}
$$

Using [16"] and [16]

$$
\begin{aligned}
& \mathrm{NPV}_{\mathrm{D}}-\mathrm{NPV}_{\mathrm{N}}=\frac{\mathrm{DTKu}}{\mathrm{Ku}-\mathrm{g}}-\frac{\mathrm{Tg}(\mathrm{D}-\mathrm{N})}{\mathrm{Ku}-\mathrm{g}}-\frac{\mathrm{NTKu}}{\mathrm{Ku}-\mathrm{g}}=\frac{\mathrm{T}}{\mathrm{Ku}-\mathrm{g}}[(\mathrm{D}-\mathrm{N}) \mathrm{Ku}-\mathrm{g}(\mathrm{D}-\mathrm{N})]= \\
& \mathrm{NPV}_{\mathrm{D}}-\mathrm{NPV}_{\mathrm{N}}=\mathrm{GOV}_{\mathrm{N}}-\mathrm{GOV}_{\mathrm{D}}=\mathrm{T}(\mathrm{D}-\mathrm{N}) \\
& \mathrm{C}_{\mathrm{N}}-\mathrm{C}_{\mathrm{D}}=(\mathrm{D}-\mathrm{N})(1-\mathrm{T})
\end{aligned}
$$

\subsection{General case}

$$
\begin{aligned}
& \mathrm{D}_{0}=\sum_{\mathrm{t}=1}^{\infty} \frac{\mathrm{N}_{\mathrm{t}-1} \mathrm{r}_{\mathrm{t}}-\left(\mathrm{N}_{\mathrm{t}}-\mathrm{N}_{\mathrm{t}-1}\right)}{\prod_{1}^{\mathrm{t}}\left(1+\mathrm{Kd}_{\mathrm{t}}\right)} \\
& \mathrm{D}_{1}=\sum_{\mathrm{t}=2}^{\infty} \frac{\mathrm{N}_{\mathrm{t}-1} \mathrm{r}_{\mathrm{t}}-\left(\mathrm{N}_{\mathrm{t}}-\mathrm{N}_{\mathrm{t}-1}\right)}{\prod_{2}^{\mathrm{t}}\left(1+\mathrm{Kd}_{\mathrm{t}}\right)} ; \frac{\mathrm{D}_{1}}{1+\mathrm{Kd}_{1}}=\sum_{\mathrm{t}=2}^{\infty} \frac{\mathrm{N}_{\mathrm{t}-1} \mathrm{r}_{\mathrm{t}}-\left(\mathrm{N}_{\mathrm{t}}-\mathrm{N}_{\mathrm{t}-1}\right)}{\prod_{1}^{\mathrm{t}}\left(1+\mathrm{Kd}_{\mathrm{t}}\right)}
\end{aligned}
$$




$$
\begin{aligned}
& D_{0}-\frac{D_{1}}{1+\mathrm{Kd}_{1}}=\frac{\mathrm{N}_{0} \mathrm{r}_{1}-\left(\mathrm{N}_{1}-\mathrm{N}_{0}\right)}{1+\mathrm{Kd}_{1}} \\
& \mathrm{D}_{1}=\mathrm{D}_{0}\left(1+\mathrm{Kd}_{1}\right)-\mathrm{N}_{0}\left(1+\mathrm{r}_{1}\right)+\mathrm{N}_{1} \\
& \mathrm{D}_{1}-\mathrm{D}_{0}=\mathrm{N}_{1}-\mathrm{N}_{0}+\mathrm{D}_{0} \mathrm{Kd}_{1}-\mathrm{N}_{0} \mathrm{r}_{1}
\end{aligned}
$$

\subsection{A formula for $K d$}

We still do not have a formula for $\mathrm{Kd}$, the «reasonable» rate that would be required by the bondholders or the bank. We can also think of $\mathrm{Kd}$ as the «reasonable» required rate of the debt flows for a person who thinks that the «reasonable» required rate for the FCF is Ku. Another way of thinking about $\mathrm{Kd}$ is to assume that debt and equity belong to the same person: if this person thinks that $\mathrm{Ku}$ is the «reasonable» required rate for the FCF, $\mathrm{Kd}$ is the «reasonable» required rate for the debt flows.

Formula [10] tells us the relationship among $\mathrm{Ku}, \mathrm{Ke}$ and $\mathrm{Kd}$ for any level of debt, but so far we do not have any formula to calculate $\mathrm{Kd}$ given $(\mathrm{Ku})$ and the debt level.

From formulas [13] or [19], we can calculate the «maximum theoretical debt» that the company can support, that is, debt when $\mathrm{C}=\mathrm{CFacc}=0$. With this leverage, $\mathrm{Kd}=\mathrm{Ku}$ because the debt supports the same risk as the unlevered equity.

On the other hand, the required rate of return for a minimum debt (think of a debt of \$1) should be RF. A formula for Kd that fulfills both requirements is [21]:

[21]

$$
; \quad K d=R_{F}+\frac{D(1-T)}{D(1-T)+C}\left(K u-R_{F}\right)
$$

which (18) means:

$$
\beta_{\mathrm{d}}=\frac{\mathrm{D}(1-\mathrm{T})}{\mathrm{D}(1-\mathrm{T})+\mathrm{C}} \beta_{\mathrm{U}}
$$

\section{[21] and [22] imply $\mathbf{K e}-\mathbf{K d}=\mathbf{K u}-\mathbf{R F}=\mathbf{b}_{\mathbf{U}} \mathbf{P M}$}

Other interesting relationships are:

$$
\mathrm{Ke}-\mathrm{Kd}=\frac{\mathrm{D}(1-\mathrm{T})+\mathrm{C}}{\mathrm{C}}(\mathrm{Ku}-\mathrm{Kd}) ; \mathrm{Ke}-\mathrm{Ku}=\frac{\mathrm{D}(1-\mathrm{T})}{\mathrm{C}}(\mathrm{Ku}-\mathrm{Kd})
$$

Note that in this paper we are considering FCF and $\mathrm{Ku}$ independent of leverage. 


\subsection{Impact on the valuation}

Exhibits 6 and 7 provide a comparison with the firm reflected in Exhibit 5 when D is different from N. To value (D), we use formula [21] in Exhibits 6 and 7. Exhibit 7 differs from Exhibit 6 in the interest rate paid by the debt: $r=17 \%$ instead of $15 \%$. Table 5 shows the differences between Exhibits 5, 6 and 7.

Table 5. Comparison of Exhibits 5, 6 and 7

$\begin{array}{lrrr}\text { (millions) } & \text { Exhibit 5 } & \text { Exhibit 6 } & \text { Exhibit 7 } \\ \text { N (Nominal value of debt) } & 1,800 & 1,800 & \\ \text { r } & 15 \% & 15 \% & 1,800 \\ & & & 17 \% \\ \text { Debt value D } & \mathbf{1 , 8 0 0} & \mathbf{1 , 7 0 5} & \mathbf{1 , 8 8 2} \\ \text { Value of shares C } & \mathbf{5 0 6} & \mathbf{5 6 8} & \mathbf{4 5 3} \\ \text { NPV of taxes paid }\left(\text { GOV }_{\mathbf{L}}\right) & \mathbf{6 1 1} & \mathbf{6 4 4} & \mathbf{5 8 2} \\ \text { SUM } & \mathbf{2 , 9 1 7} & \mathbf{2 , 9 1 7} & \mathbf{2 , 9 1 7}\end{array}$

Table 6 has more information about the impact of further changes in $r$ (in Exhibits 6 and 7) on the value of the different stakeholders of the company. To value D, we get Kd using formula [21].

Table 6. Influence of $r$ on the value of shares (C), debt (D) and NPV of taxes paid $\left(G O V_{L}\right)$ Changes in the values of Exhibits 6 and 7

$\begin{array}{lccccc}\mathbf{r} & \begin{array}{c}\text { (in t=0) } \\ \text { Kd }\end{array} & \begin{array}{c}\text { Face value } \\ \text { of debt } \\ \mathbf{N}\end{array} & \begin{array}{c}\text { Value of } \\ \mathbf{d e b t} \\ \mathbf{D}\end{array} & \begin{array}{c}\text { Value of } \\ \text { shares } \\ \mathbf{C}\end{array} & \begin{array}{c}\text { NPV of } \\ \text { taxes paid } \\ \left(\mathbf{G O V}_{\mathbf{L}}\right)\end{array} \\ \mathbf{1 4 \%} & 17.00 \% & 1800 & 1612 & 628 & 677 \\ 15 \% \text { (Exhibit 6) } & 17.29 \% & 1800 & 1705 & 568 & 644 \\ 16 \% & 17.57 \% & 1800 & 1794 & 510 & 613 \\ 17 \% \text { (Exhibit } 7) & 17.84 \% & 1800 & 1882 & 453 & 582 \\ 18 \% & 18.11 \% & 1800 & 1969 & 397 & 551 \\ 19 \% & 18.37 \% & 1800 & 2053 & 342 & 522 \\ 20 \% & 18.63 \% & 1800 & 2136 & 288 & 493 \\ 21 \% & 18.88 \% & 1800 & 2217 & 235 & 465\end{array}$

(1) I would like to thank CIIF (International Center for Finance Research) and its director Natalia Centenera for their financial support and for their encouragement. Professor Rafael Termes gave me the initial push to think about these valuation issues.

I also would like to thank Prof. Carliss Baldwin (my main professor of corporate finance and the director of my dissertation committee at Harvard), Prof. Timothy Luehrman and Prof. Scott Mason, who taught me the correct way to approach the issues in this paper.

Finally, I would like to acknowledge the help of my MBA and PhD students at IESE, who encouraged me to think about the valuation formulas that appear in this paper. I wish to thank specially Christopher Golembiewski for his suggestions. 
(2) This paper is based on a 90-page note that I have in Spanish for my second-year MBA students. The Spanish version includes more examples and comments; the impact of using reduced formulas for $\beta_{\mathrm{L}}$; charts, etc.

(3) Note that $\mathrm{FCF}=\mathrm{CFacc}$ when the company has no debt

(4) We assume that $\mathrm{Kd}$ (required return for debt) is equal to the interest rate that the company pays for the debt (r). In this situation, D (value of debt) is equal to par value. In section 5 we will show how formulas change when $\mathrm{Kd} \neq \mathrm{r}$, and will provide a tentative formula for $\mathrm{Kd}$.

(5) This equality only holds for perpetuities with no growth. For other companies see sections 3 and 4 of this paper.

(6) Note that FCF and FCFo have the same risk. Their required rate of return is $\mathrm{Ku}$.

(7) $\mathrm{PAT}=\mathrm{PBT}(1-\mathrm{T})$. PBT is the profit before taxes.

(8) Note that $[3 p]$ assumes Modigliani-Miller. It also assumes that FCF is independent of leverage. We are not considering bankruptcy costs.

(9) Another consequence of [12] is that if T is large enough, WACC can be smaller than $\mathrm{R}_{\mathrm{F}}$.

(10) In Exhibits 1 to 5 it will be clear that, in general, $\mathrm{PBT}_{\mathrm{U}} \neq \mathrm{FCF}_{0}$.

(11) For simplicity, we will assume that $\mathrm{H}$ is proportional to FCFo, then FCF and FCFo have the same risk: their required rate of return would be $\mathrm{Ku}$. But this assumption is not necessary for the conclusions of this paper.

(12) $\mathrm{K}_{\mathrm{TL}}$ is the required return for the taxes paid by the levered company.

(13) In Appendix 1 we show what happens if we consider the «traditional» (and wrong) formula that says: NPV of interest tax shields = DT Kd / $(\mathrm{Kd}-\mathrm{g})$. We show that if we use this formula, then [10] does not apply; $\beta_{\mathrm{L}}$ and $\mathrm{Ke}$ have to be dependent on $\mathrm{g}$; and other inconsistencies. All these inconsistencies come from considering the «NPV of interest tax shields» as the NPV of a flow (DT Kd), when it is the difference of two NPVs of two flows with different risk: the NPV of the taxes paid in the unlevered firm and the NPV of taxes paid in the levered firm.

(14) Note that $\mathrm{Ke}=\mathrm{K}_{\mathrm{TL}}$ if $\mathrm{H}=\mathrm{gD}$

(15) In this situation, $\mathrm{C}=\mathrm{CFacc}=0$. It seems that the full cash-flow (FCFo) generated by the company goes to the debt, but Taxes $_{\mathrm{L}}=\mathrm{T}(\mathrm{H}-\mathrm{gDo}) /(1-\mathrm{T}) ; \mathrm{GOV}_{\mathrm{L}}=[\mathrm{T} /(1-\mathrm{T})][(\mathrm{H}-\mathrm{gDo}) /(\mathrm{Ku}-\mathrm{g})]$. Also $\mathrm{Kd}=\mathrm{K}_{\mathrm{TL}}=\mathrm{Ku}$.

(16) The three valuation methods give the same value for any company. Also, when RF changes over time and when $\mathrm{Ku}$ changes over time.

(17) We can also think of $\mathrm{Kd}$ as the «reasonable» required rate of the debt flows for a person who believes the «reasonable» required rate for the $\mathrm{FCF}$ is $\mathrm{Ku}$.

(18) An alternative formula could be $K d=R_{F}+\left(K u-R_{F}\right) D /(D+C)$, but then $(K e-K d)$ decreases with leverage, which is not very sensible. 
Exhibit 1

EQUIVALENCE OF THE APV, WACC AND FLOWS TO EQUITY APPROACHES TO FIRM VALUATION

$$
\mathrm{D}=500 ; \text { Growth }=5.00 \% ; \mathrm{T}=35.00 \% ; \Delta \text { Net fixed assets }=0 \text {. }
$$

\begin{tabular}{|c|c|c|c|c|c|c|c|}
\hline & & 0 & 1 & 2 & 3 & 4 & $g$ \\
\hline 1 & Required cash & 100 & 105 & 110.25 & 115.76 & 121.55 & $5.00 \%$ \\
\hline 2 & Receivables & 900 & 945 & 992.25 & $1,041.86$ & $1,093.96$ & $5.00 \%$ \\
\hline 3 & Stocks & 240 & 252 & 264.60 & 277.83 & 291.72 & $5.00 \%$ \\
\hline 4 & Gross fixed assets & 1200 & 1410 & $1,630.50$ & $1,862.03$ & $2,105.13$ & $13.06 \%$ \\
\hline 5 & - accum. depreciation & 200 & 410 & 630.50 & 862.03 & $1,105.13$ & $28.20 \%$ \\
\hline 6 & Net fixed assets & 1000 & 1000 & $1,000.00$ & $1,000.00$ & $1,000.00$ & $0.00 \%$ \\
\hline 7 & TOTAL ASSETS & 2,240 & 2,302 & $2,367.10$ & $2,435.46$ & $\mathbf{2 , 5 0 7 . 2 3}$ & $2,95 \%$ \\
\hline 8 & Acc. payable & 240 & 252 & 264.60 & 277.83 & 291.72 & $5.00 \%$ \\
\hline 9 & Debt & 500 & 525 & 551.25 & 578.81 & 607.75 & $5.00 \%$ \\
\hline 10 & Net Worth (book value) & 1500 & 1525 & $1,551.25$ & $1,578.81$ & $1,607.75$ & $1.83 \%$ \\
\hline 11 & TOTAL LIAB. \& NW & 2,240 & 2,302 & $2,367.10$ & $2,435.46$ & $2,507.23$ & $2.95 \%$ \\
\hline 12 & WCR & 1,000 & 1,050 & $1,102.50$ & $1,157.63$ & $1,215.51$ & $5.00 \%$ \\
\hline 14 & Sales & 3,000 & 3150 & $3,307.50$ & $3,472.88$ & $3,646.52$ & $5.00 \%$ \\
\hline 15 & Cost of sales & 1,200 & 1260 & $1,323.00$ & $1,389.15$ & $1,458.61$ & $5.00 \%$ \\
\hline 16 & General, selling \& adm. expen. & 600 & 630 & 661.50 & 694.58 & 729.30 & $5.00 \%$ \\
\hline 17 & Depreciation & 200 & 210 & 220.50 & 231.53 & 243.10 & $5.00 \%$ \\
\hline 18 & PBIT & 1000 & 1050 & $1,102.50$ & $1,157.63$ & $1,215.51$ & $5.00 \%$ \\
\hline 19 & Interest & 75 & 75 & 78.75 & 82.69 & 86.82 & $5.00 \%$ \\
\hline 20 & PBT & 925 & 975 & $1,023.75$ & $1,074.94$ & $1,128.68$ & $5.00 \%$ \\
\hline 21 & Taxes $(35 \%)$ & 323.75 & 341.25 & 358.31 & 376.23 & 395.04 & $5.00 \%$ \\
\hline 22 & PAT & 601.25 & 633.75 & 665.44 & 698.71 & 733.64 & $5.00 \%$ \\
\hline 23 & + Depreciation & 200 & 210 & 220.50 & 231.53 & 243.10 & $5.00 \%$ \\
\hline 24 & $+\Delta$ Debt & & 25 & 26.25 & 27.56 & 28.94 & $5.00 \%$ \\
\hline 25 & $-\Delta \mathrm{WCR}$ & & -50 & -52.50 & -55.13 & -57.88 & $5.00 \%$ \\
\hline 26 & - Payments of fixed assets & & -210 & -220.50 & -231.53 & -243.10 & $5.00 \%$ \\
\hline 27 & CFacc & & 608.75 & 639.19 & 671.15 & $\mathbf{7 0 4 . 7 0}$ & $5.00 \%$ \\
\hline 28 & FCF & & 632.5 & 664.13 & 697.33 & 732.20 & $5.00 \%$ \\
\hline 37 & Beta U & 1.000000 & 1.000000 & 1.000000 & 1.000000 & 1.000000 & \\
\hline 38 & $\mathrm{Rf}$ & $12.00 \%$ & $12.00 \%$ & $12.00 \%$ & $12.00 \%$ & $12.00 \%$ & \\
\hline 39 & $\mathrm{Rm}-\mathrm{Rf}$ & $8.00 \%$ & $8.00 \%$ & $8.00 \%$ & $8.00 \%$ & $8.00 \%$ & \\
\hline 40 & $\mathrm{Ku}$ & $20.00 \%$ & $20.00 \%$ & $20.00 \%$ & $20.00 \%$ & $20.00 \%$ & \\
\hline 41 & $\mathbf{V u}=\mathbf{F C F} /(\mathbf{K u}-\mathbf{g})$ & $4,216.67$ & $4,427.50$ & $4,648.87$ & $4,881.32$ & $5,125.38$ & \\
\hline 43 & FCFo $=$ FCF without taxes & & $1,000.00$ & $1,050.00$ & $1,102.50$ & $1,157.63$ & $5.00 \%$ \\
\hline 44 & Vu without taxes & $6,666.67$ & $7,000.00$ & $7,350.00$ & $7,717.50$ & $8,103.37$ & \\
\hline 45 & $\operatorname{Taxes}_{\mathrm{u}}$ & & 367.50 & 385.88 & 405.17 & 425.43 & $5.00 \%$ \\
\hline 46 & $\mathrm{GOV}_{\mathrm{u}}^{\mathrm{u}}=\operatorname{Taxes}_{\mathrm{u}} /(\mathrm{Ku}-\mathrm{g})$ & $2,450.00$ & $2,572.50$ & $2,701.12$ & $2,836.18$ & $2,977.99$ & $5.00 \%$ \\
\hline 47 & $\mathrm{Vu}+\mathrm{GOV}_{\mathrm{u}}$ & $6,666.67$ & $7,000.00$ & $7,350.00$ & $7,717.50$ & $8,103.37$ & $5.00 \%$ \\
\hline 48 & $\mathrm{D}$ & 500.00 & 525.00 & 551.25 & 578.81 & 607.75 & $5.00 \%$ \\
\hline 49 & $\mathrm{Kd}$ & $15.00 \%$ & $15.00 \%$ & $15.00 \%$ & $15.00 \%$ & $15.00 \%$ & \\
\hline 50 & Beta d & 0.375000 & 0.375000 & 0.375000 & 0.375000 & 0.375000 & \\
\hline 51 & $\mathrm{DTKu} /(\mathrm{Ku}-\mathrm{g})=\mathrm{NPV}$ int. tax shield. & 233.33 & 245.00 & 257.25 & 270.11 & 283.62 & $5.00 \%$ \\
\hline 52 & NPV int. tax shield. $+\mathrm{Vu}$ & $4,450.00$ & $4,672.50$ & $4,906.12$ & $5,151.43$ & $5,409.00$ & $5.00 \%$ \\
\hline 53 & $-\mathbf{D}=\mathbf{C}$ & 3,950 & 4,148 & 4,355 & 4,573 & 4,801 & $5.00 \%$ \\
\hline 54 & Beta L & 1.051424 & 1.051424 & 1.051424 & 1.051424 & 1.051424 & $0.00 \%$ \\
\hline 55 & $\mathrm{Ke}$ & $20.41 \%$ & $20.41 \%$ & $20.41 \%$ & $20.41 \%$ & $20.41 \%$ & $0.00 \%$ \\
\hline 56 & $\mathrm{C}=\mathrm{CFacc} /(\mathrm{Ke}-\mathbf{g})$ & 3,950 & 4,148 & 4,355 & 4,573 & 4,801 & $5.00 \%$ \\
\hline 59 & WACC & $19.2135 \%$ & $19.2135 \%$ & $19.2135 \%$ & $19,2135 \%$ & $19.2135 \%$ & $0.00 \%$ \\
\hline 60 & $\mathrm{D}+\mathrm{E}=\mathrm{FCF} /(\mathrm{WACC}-\mathrm{g})$ & $4,450.00$ & $4,672.50$ & $4,906.13$ & $5,151.43$ & $5,409.00$ & $5.00 \%$ \\
\hline 61 & $-\mathbf{D}=\mathbf{C}$ & 3,950 & 4,148 & 4,355 & $\mathbf{4 , 5 7 3}$ & 4,801 & $5.00 \%$ \\
\hline \multicolumn{8}{|c|}{ Two ways of calculating the NPV of interest tax shields: } \\
\hline 51 & DTKu/(Ku-g) & 233.33 & 245.00 & 257.25 & 270.11 & 283.62 & $5.00 \%$ \\
\hline 62 & DTKd/(Kd-g) & 262.50 & 275.63 & 289.41 & 303.88 & 319.07 & $5.00 \%$ \\
\hline
\end{tabular}


Exhibit 1 (continued)

D $=500 ;$ Growth $=5.00 \% ; T=35.00 \% ; \Delta$ Net fixed assets $=5 \%$.

Required cash

Receivables

Stocks

Gross fixed assets

- accum. depreciation

Net fixed assets

TOTAL ASSETS

Acc. payable

Debt

Net Worth (book value)

TOTAL LIAB. \& NW

WCR

$\boldsymbol{P} \& \boldsymbol{L} \quad$ Sales

$15 \quad$ Cost of sales

General, selling \& adm. expen.

Deprecitation

PBIT

Interest

PBT

Taxes

PAT

+ Depreciation

$+\Delta$ Debt

- $\Delta$ WCR

- Payments of fixed assets

CFacc

FCF

Beta $\mathrm{U}$

$\mathrm{Rf}$

$\mathrm{Rm}-\mathrm{Rf}$

$\mathrm{Ku}$

$\mathrm{Vu}=\mathrm{FCF} /(\mathrm{Ku}-\mathrm{g})$

FCFo $=$ FCF without taxes

Vu without taxes

Taxes u

$\mathrm{GOV} \mathrm{u}=\mathrm{IMPu} /(\mathrm{Ku}-\mathrm{g})$

$\mathrm{Vu}+\mathrm{GOV} \mathrm{u}$

D

Kd

$\mathrm{DTKu} /(\mathrm{Ku}-\mathrm{g})=\mathrm{NPV}$ int. tax shield NPV int. tax shield $+\mathrm{Vu}$

$53-\mathrm{D}=\mathrm{C}$

Beta E

$\mathrm{Ke}$

$\mathrm{C}=\mathrm{CFacc} /(\mathrm{Ke}-\mathrm{g})$

WACC

$60 \mathrm{D}+\mathrm{E}=\mathrm{FCF} /($ WACC-g $)$

$61-\mathrm{D}=\mathbf{C}$
100

900

240

1200

200

1000

$\mathbf{2 , 2 4 0}$

240

500

500
1500

$\mathbf{2 , 2 4 0}$

1,000

3000

1200

600

200

1000

75

925

323.75

601.25

200

.

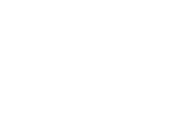
1.00000
$12.00 \%$
$8.00 \%$
$20.00 \%$

$3,888.33$

$6,333.33$

.

$2,450.00$

$6,333.33$

500.00

$15.00 \%$

0.375000

233.33

4,116.67

$\mathbf{3 , 6 1 7}$

1.056164
$20.45 \%$

$20.45 \%$

3,617

$19.1498 \%$

$4,116.67$

$\mathbf{3 , 6 1 7}$
105

945

252

1460

410

1050

2,352

252

525

1575

2,352

1,050

3150

1260

630

210

1050

75

975

341.25

633.75

210

25

$-50$

$-260$

558.75

582.5

1.000000

$12.00 \%$

$8.00 \%$

$20.00 \%$

$4,077.50$

950.00

$6,650.00$

367.50

$2,572.50$

$6,650.00$

525.00

$15.00 \%$

0.375000

245.00

$4,322.50$

$\mathbf{3 , 7 9 7}$

1.056164

$20.45 \%$

3,798

$19.1498 \%$

$4.322,50$
$\mathbf{3 , 7 9 8}$

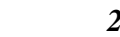

110.25

992.25

264.60

1733

630.50

1102.5

$2,469.60$

264.60

551.25

$1,653.75$

$\mathbf{2 , 4 6 9 . 6 0}$

$1,102.50$

$3,307.50$

$1,323.00$

661.50

220.50

$1,102.50$

78.75

$1,023.75$

358.31

$\mathbf{6 6 5 . 4 4}$

220.50

26.25

$-52.50$

$-273.00$

$\mathbf{5 8 6 . 6 9}$

611.63

1.000000

$12.00 \%$

$8.00 \%$

$20.00 \%$

$4,281.37$

997.50

$6,982.50$

385.88

$2,701.12$

$6,982.50$

551.25

$15.00 \%$

0.375000

257.25

$4,538.62$

$\mathbf{3 , 9 8 7}$

1.056164

$20.45 \%$

$\mathbf{3 , 9 8 7}$

$19.1498 \%$

4,538.62

$\mathbf{3 , 9 8 7}$

257.25

289.41
245.00

233.33

262.50

275.63
DTKd/(Kd-g)
62

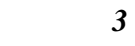

115.76

$1,041.86$

277.83

2019.65

862.03

1157.625

2,593.08

277.83

578.81

$1,736.44$

2,593.08

$1,157.63$

$3,472.88$

$1,389.15$

694.58

231.53

$1,157.63$

82.69

1,074.94

376.23

698.71

231.53

27.56

$-55.13$

$-286.65$

616.02

642.21

121.55

$1,093.96$

291.72

2320.6325

$1,105.13$

1215.5063

$\mathbf{2 , 7 2 2 . 7 3}$

291.72

607.75

$1,823.26$

$\mathbf{2 , 7 2 2 . 7 3}$

$1,215.51$

$3,646.52$

$1,458.61$

729.30

243.10

$1,215.51$

86.82

$1,128.68$

395.04

733.64

243.10

28.94

$-57.88$

$-300.98$

646.82

674.32

1.000000

$12.00 \%$

$8.00 \%$

$20.00 \%$

$4,495.44$

1.000000

$12.00 \%$

$8.00 \%$

$20.00 \%$

$4,720.22$

$1,047.38$

$1,099.74$

$7,698.21$

$5.00 \%$

$7,331.63$

405.17

$2,836.18$

425.43

$2,977.99$ 
Exhibit 2

EQUIVALENCE OF THE APV, WACC AND FLOWS TO EQUITY APPROACHES
TO FIRM VALUATION

$D=500 ;$ Growth $=5.00 \% ; T=0 \% ; \Delta$ Net fixed assets $=0$.

Required cash

Receivables

Stocks

Gross fixed assets

- accum. depreciation

Net fixed assets

TOTAL ASSETS

Acc. payable

Debt

Net Worth (book value)

TOTAL LIAB. \& NW

WCR

$P \& L$ Sales

Cost of sales

General, selling \& adm. expen.

Depreciation

PBIT

Interest

PBT

Taxes

PAT

+ Depreciation

$+\Delta$ Debt

- $\Delta$ WCR

- Payments of fixed assets

CFacc

FCF

Beta U

Rf

$\mathrm{Rm}-\mathrm{Rf}$

$\mathrm{Ku}$

$\mathrm{Vu}=\mathrm{FCF} /(\mathrm{Ku}-\mathrm{g})$

FCFo $=$ FCF without taxes

$\mathrm{Vu}$ without taxes

Taxes $\mathrm{u}$

$\mathrm{GOV} \mathrm{u}=\mathrm{IMPu} /(\mathrm{Ku}-\mathrm{g})$

$\mathrm{Vu}+\mathrm{GOV} \mathrm{u}$

D

$\mathrm{Kd}$

$\mathrm{DTKu} /(\mathrm{Ku}-\mathrm{g})=\mathrm{NPV}$ int. tax shield NPV int. tax shield + Vu

$53-\mathbf{D}=\mathbf{C}$

$54 \quad$ Beta E

$55 \quad \mathrm{Ke}$

$56 \quad \mathrm{C}=\mathrm{CFacc} /(\mathrm{Ke}-\mathrm{g})$

59 WACC

$60 \mathrm{D}+\mathrm{E}=\mathrm{FCF} /($ WACC-g)

61 - D = C

\section{0}

\section{0}

900

240

1200

200

1000

$\mathbf{2 , 2 4 0}$

240

500

1500

$\mathbf{2 , 2 4 0}$

1,000

3000

1200

600

200

1000

75
925
0

0

925

200$$
\begin{array}{r}
1.00000 \\
12.00 \% \\
8.00 \% \\
20.00 \% \\
6,666.67
\end{array}
$$$$
\begin{array}{r}
20.00 \% \\
6,666.67
\end{array}
$$

$6,666.67$

$7,000.00$

$$
\begin{array}{rr} 
& 0.00 \\
0.00 & 0.00 \\
6,666.67 & 7,000.00
\end{array}
$$

500.00

$15.00 \%$

0.375000

0.00

$6,666.67$

6,167

1.050676

$20.41 \%$

6,167

525.00

$15.00 \%$

0.375000

0.00

$7,000.00$

6,475

1.050676

$20.41 \%$

6,475

$20.0000 \%$ $6,666.67$

$\mathbf{6 , 1 6 7}$
$20.0000 \%$

$7,000.00$

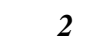

110.25

992.25

264.60

$1,630.50$

630.50

$1,000.00$

2,367.10

264.60

551.25

$1,551.25$

2,367.10

$1,102.50$

$3,307.50$

$3,307.50$
$1,323.00$

661.50

220.50

$1,102.50$

78.75

$1,023.75$

0.00

1,023.75

220.50

26.25

$-52.50$

$-220.50$

$\mathbf{9 9 7 . 5 0}$

$1,050.00$

1.000000

$12.00 \%$

$8.00 \%$

$20.00 \%$

$7,350.00$

$1,050.00$

$7,350.00$

0.00

0.00

7,350.00

551.25

$15.00 \%$

0.375000

0.00

$7,350.00$

6,799

1.050676

$20.41 \%$

6,799

$20.0000 \%$

$7,350.00$ $\mathbf{6 , 7 9 9}$

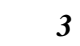

115.76

$1,041.86$

277.83

$1,862.03$

862.03

$1,000.00$

$\mathbf{2 , 4 3 5 . 4 6}$

277.83

578.81

$1,578.81$

$\mathbf{2 , 4 3 5 . 4 6}$

$1,157.63$

$3,472.88$

$1,389.15$

694.58

231.53

$1,157.63$

82.69

$1,074.94$

0.00

1,074.94

231.53

27.56

$-55.13$

$-231.53$

1,047.38

$1,102.50$

1.000000

$12.00 \%$

$8.00 \%$

$20.00 \%$

$7,717.50$

$1,102.50$

$7,717.50$

0.00

0.00

$7,717.50$

578.81

$15.00 \%$

0.375000

0.00

$7,717.50$

7,139

1.050676

$20.41 \%$

7,139

$20.0000 \%$

$7,717.50$

$\mathbf{7 , 1 3 9}$

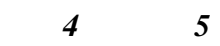

$121.55 \quad 127.63$

$1,093.96 \quad 1,148.65$

$291.72 \quad 306.31$

$2,105.13 \quad 2,360.38$

$1,105.13 \quad 1,360.38$

$1,000.00 \quad 1,000.00$

$\mathbf{2 , 5 0 7 . 2 3} \mathbf{2 , 5 8 2 . 5 9}$

$291.72 \quad 306.31$

$607.75 \quad 638.14$

$1,607.75 \quad 1,638.14$

$\mathbf{2 , 5 0 7 . 2 3} \quad \mathbf{2 , 5 8 2 . 5 9}$

$1,215.51 \quad 1,276.28$

$3,646.52 \quad 3,828.84$

$1,458.61 \quad 1,531.54$

$729.30 \quad 765.77$

$243.10 \quad 255.26$

$1,215.51 \quad 1,276.28$

$86.82 \quad 91.16$

$1,128.68 \quad 1,185.12$

$0.00 \quad 0.00$

$\mathbf{1 , 1 2 8 . 6 8} 1,185.12$

$243.10 \quad 255.26$

$\begin{array}{rr}28.94 & 30.39\end{array}$

$-57.88 \quad-60.78$

$\begin{array}{ll}-243.10 & -255.26\end{array}$

$1,099.74 \quad 1,154.73$

$1,157.63 \quad 1,215.51$

$1.000000 \quad 1.000000$

$12.00 \% \quad 12.00 \%$

$8.00 \% \quad 8.00 \%$

$20.00 \% \quad 20.00 \%$

$8,103.37 \quad 8,508.54$

$1,157.63 \quad 1,215.51$

$8,103.37 \quad 8,508.54$

$0.00 \quad 0.00$
0.00

$8,103.37 \quad 8,508.54$

$607.75 \quad 638.14$

$15.00 \% \quad 15.00 \%$

$\begin{array}{ll}0.375000 & 0.375000\end{array}$

$0.00 \quad 0.00$

$8,103.37 \quad 8,508.54$

$\mathbf{7 , 4 9 6} \mathbf{7 , 8 7 0}$

$1.050676 \quad 1.050676$

$20.41 \% \quad 20.41 \%$

$\mathbf{7 , 4 9 6} \mathbf{7 , 8 7 0}$

$20.0000 \% 20.0000 \%$

$8,103.37 \quad 8,508.54$ 
Exhibit 3

EQUIVALENCE OF THE APV, WACC AND FLOWS TO EQUITY APPROACHES TO FIRM VALUATION

D $=0 ;$ Growth $=5.00 \% ; T=0 \% ; \Delta$ Net fixed assets $=0$

Required cash

Receivables

Stocks

Gross fixed assets

- accum. depreciation

Net fixed assets

TOTAL ASSETS

Acc. payable

Debt

Net Worth (book value)

TOTAL LIAB. \& NW

WCR

$P \& L \quad$ Sales

15 Cost of sales

General, selling \& adm. expen.

Depreciation

PBIT

Interest

PBT

Taxes

PAT

+ Depreciation

$+\Delta$ Debt

$-\triangle \mathrm{WCR}$

- Payments of fixed assets

CFacc

FCF

Beta U

$\mathrm{Rf}$

$\mathrm{Rm}$ - Rf

$\mathrm{Ku}$

$\mathrm{Vu}=\mathrm{FCF} /(\mathrm{Ku}-\mathrm{g})$

FCFo $=$ FCF without taxes

$\mathrm{Vu}$ without taxes

Taxes u

$\mathrm{GOV} \mathrm{u}=\mathrm{IMPu} /(\mathrm{Ku}-\mathrm{g})$

$\mathrm{Vu}+\mathrm{GOV} \mathrm{u}$

D

$\mathrm{Kd}$

Beta d

$51 \quad \mathrm{DTKu} /(\mathrm{Ku}-\mathrm{g})=\mathrm{NPV}$ int. tax shield

$\mathbf{5 3}-\mathbf{D}=\mathbf{C}$

NPV int. tax shield $+\mathrm{Vu}$

$\begin{array}{ll}54 & \text { Beta E } \\ 55 & \mathrm{Ke}\end{array}$

$56 \quad \mathrm{C}=\mathrm{CFacc} /(\mathrm{Ke}-\mathrm{g})$

59 WACC

$60 \mathrm{D}+\mathrm{E}=\mathrm{FCF} /(\mathrm{WACC}-\mathrm{g})$

61- D = C

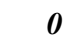

$\begin{array}{rr}100 & 105 \\ 900 & 945 \\ 240 & 252 \\ 1200 & 1410 \\ 200 & 410 \\ 1000 & 1000 \\ 2,240 & 2,302\end{array}$

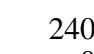

2000

2,240

1,000

3000

1200

600

200

1000

0

1000
0

1000

200

.

1.000000

$12.00 \%$

$8.00 \%$

$20.00 \%$

$6,666.67$

$6,666.67$

$1,000.00$

0.00

0.00

$6,666.67$

0.00

7,000.00

$\begin{array}{ll}0.00 & 0.00\end{array}$

$15.00 \%$

0.375000

$15.00 \%$

0.375000

0.00
$6,666.67$

$\mathbf{6 , 6 6 7}$

0.00

$7,000.00$

$\mathbf{7 , 0 0 0}$

$1.000000 \quad 1.000000$

$20.00 \%$

$\mathbf{6 , 6 6 7}$

$20.00 \%$

$\mathbf{7 , 0 0 0}$

$20.0000 \% \quad 20.0000 \%$

$6,666.67 \quad 7,000.00$

$\mathbf{6 , 6 6 7}$

\section{2}

110.25

992.25

264.60

$1,630.50$

630.50

$1,000.00$

$2,367.10$

264.60

0.00

$2,102.50$

$2,367.10$

$1,102.50$

$3,307.50$

$1,323.00$

661.50

220.50

$1,102.50$

0.00

$1,102.50$

0.00

$1,102.50$

220.50

0.00

$-52.50$

$-220.50$

$\mathbf{1 , 0 5 0 . 0 0}$

$\mathbf{1 , 0 5 0 . 0 0}$

1.000000

$12.00 \%$

$8.00 \%$

$20.00 \%$

$7,350.00$

$1,050.00$

$7,350.00$

0.00

0.00

$7,350.00$

0.00

$15.00 \%$

0.375000

0.00

$7,350.00$

$\mathbf{7 , 3 5 0}$

1.000000

$20.00 \%$

$\mathbf{7 , 3 5 0}$

$20.0000 \%$

$7,350.00$
$\mathbf{7 , 3 5 0}$

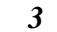

115.76

$1,041.86$

277.83

$1,862.03$

862.03

$1,000.00$

$2,435.46$

277.83

0.00

$2,157.63$

$2,435.46$

$1,157.63$

$3,472.88$

$1,389.15$

694.58

231.53

$1,157.63$

0.00

$1,157.63$

0.00

1,157.63

231.53

0.00

$-55.13$

$-231.53$

$\mathbf{1 , 1 0 2 . 5 0}$

$1,102.50$

1.000000

$12.00 \%$

$8.00 \%$

$20.00 \%$

$7,717.50$

$1,102.50$

$7,717.50$

0.00

0.00
717.50

$7,717.50$

0.00

$15.00 \%$

0.375000

0.00

$7,717.50$

$\mathbf{7 , 7 1 8}$

1.000000

$20.00 \%$

$\mathbf{7 , 7 1 8}$

$20.0000 \%$

$7,717.50$

$\mathbf{7 , 7 1 8}$
$1,093.96$

291.72

$2,105.13$

$1,105.13$

$1,000.00$

$2,507.23$

291.72

0.00

2,215.51

$2,507.23$

$1,215.51$

$3,646.52$

$1,458.61$

729.30

243.10

$1,215.51$

0.00

$1,215.51$

0.00

1,215.51

243.10

0.00

$-57.88$

$-243.10$

1,157.63

$\mathbf{1 , 1 5 7 . 6 3}$

1.000000

$12.00 \%$

$8.00 \%$

$20.00 \%$

$8,103.37$

$1,157.63$

$8,103.37$

0.00

0.00

$8,103.37$

0.00

$15.00 \%$

0.375000

0.00

$8,103.37$

$\mathbf{8 , 1 0 3}$

1.000000

$20.00 \%$

8,103

$20.0000 \% \quad 20.0000 \%$

$8,103.37 \quad 8,508.54$
$20.00 \%$

127.63

$1,148.65$

306.31

$1,360.38$

$1,000.00$

$2,582.59$

306.31

$2,276.28$

2,582.59

$1,276.28$

$3,828.84$

$1,531.54$

765.77
255.26

$1,276.28$

0.00

$1,276.28$

$\mathbf{1 , 2 7 6 . 2 8}$

255.26

0.00

-60.78
-255.26

1,215.51

$1,215.51$

000000

$8.00 \%$

$20.00 \%$

$8,508.54$

$1,215.51$

$8,508.54$

0.00

$8,508.54$

$15.00 \%$

0.375000

0.00
8.508 .54

$\mathbf{8 , 5 0 9}$

8,509 
Exhibit 4

EQUIVALENCE OF THE APV, WACC AND FLOWS TO EQUITY APPROACHES TO FIRM VALUATION

D = 0; Growth $=5.00 \% ; T=35 \% ; \Delta$ Net fixed assets $=0$.

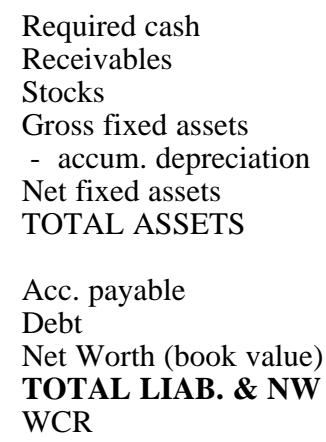

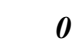

100

900

240

1200

200

1000

2,240

240

2000

$\mathbf{2 , 2 4 0}$

1,000

3000

1200

600

200

1000

1000

350

650

200

(1)

1.000000

$12.00 \%$

$8.00 \%$

$20.00 \%$

4,216.67

$6,666.67$

$2,450.00$

6,666.67

$$
0.00
$$

$15.00 \%$

0.375000

0.00

4,216.67

$\mathbf{4 , 2 1 7}$

1.000000

$20.00 \%$

$\mathbf{4 , 2 1 7}$

$20.0000 \%$

4,216.67

$\mathbf{4 , 2 1 7}$

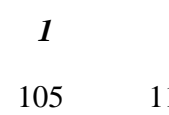

105
945

252

1410

410

1000

2,302

252

2050

$\mathbf{2 , 3 0 2}$

1,050

3150

1260

630

210

1050

1050

367.5

682.5

210

0
-50

$-210$

632.5

632.5

2

110.25

992.25

264.60

1.630 .50

630.50

1.000 .00

$2,367.10$

264.60

0.00

$2,102.50$

2,367.10

$1,102.50$

$3,307.50$

$1,323.00$

661.50

220.50

$1,102.50$

0.00

$1,102.50$

385.88

716.63

220.50

0.00

$-52.50$

$-220.50$

664.13

664.13

1000000

$12.00 \%$

$8.00 \%$

$20.00 \%$

4,648.87

$\mathbf{4 , 4 2 7 . 5 0}$

$1,000.00$

$1,050.00$

$7,350.00$

367.50

$2,572.50$

7,000.00

385.88

$2,701.12$

$7,350.00$

0.00

$15.00 \%$

0.375000

0.00

4,427.50

$\mathbf{4 , 4 2 8}$

0.00

$15.00 \%$

0.375000

0.00

4,648.87

4,649

1.000000

$20.00 \%$

$\mathbf{4 , 6 4 9}$

$\mathbf{4 , 4 2 8}$

$20.0000 \%$

$4,648.87$

$\mathbf{4 , 6 4 9}$

$\mathbf{4 , 4 2 8}$

\section{3}

115.76

$1,041.86$

277.83

$1,862.03$

862.03

$1,000.00$

$2,435.46$

277.83

$\begin{array}{r}0.00 \\ \hline\end{array}$

$2,157.63$
$\mathbf{2 , 4 3 5 . 4 6}$

$1,157.63$

$3,472.88$

$1,389.15$

694.58

231.53

$1,157.63$

0.00

$1,157.63$

405.17

$\mathbf{7 5 2 . 4 6}$

231.53

0.00

$-55.13$

$-231.53$

697.33

697.33

1.000000

$12.00 \%$

$8.00 \%$

$20.00 \%$

4,881.32

$1,102.50$

$7,717.50$

405.17

2,836.18

$7,717.50$

0.00

$15.00 \%$

0.375000

0.00

$4,881.32$

4,881

1.000000

$20.00 \%$

$\mathbf{4 , 8 8 1}$

$20.0000 \%$

$4,881.32$

$\mathbf{4 , 8 8 1}$

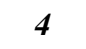

121.55

$1,093.96$

291.72

$2,105.13$

$1,105.13$

$1,000.00$

$2,507.23$

291.72

0.00

$2,215.51$

2,507.23

$1,215.51$

3,646.52

$1,458.61$

729.30

243.10

$1,215.51$

0.00

$1,215.51$

425.43

790.08

243.10

0.00

$-57.88$

$-243.10$

732.20

732.20

1.000000

$12.00 \%$

$8.00 \%$

$20.00 \%$

$\mathbf{5 , 1 2 5 . 3 8}$

$1,157.63$

$8,103.37$

425.43

$2,977.99$

$8,103.37$

0.00

$15.00 \%$

0.375000

0.00

$5,125.38$

$\mathbf{5 , 1 2 5}$

1.000000

$20.00 \%$

$\mathbf{5 , 1 2 5}$

$20.0000 \%$

, 125.38 


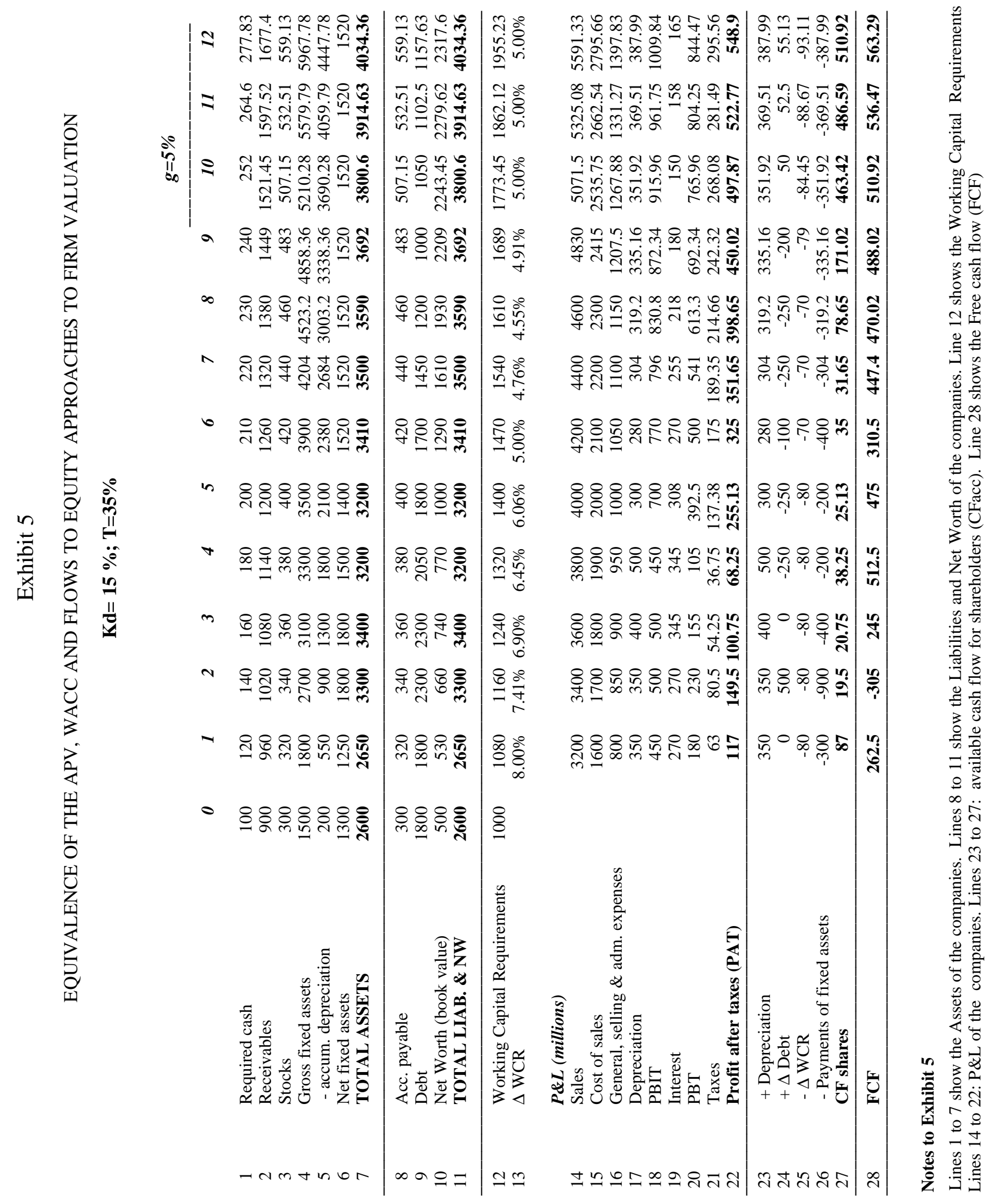




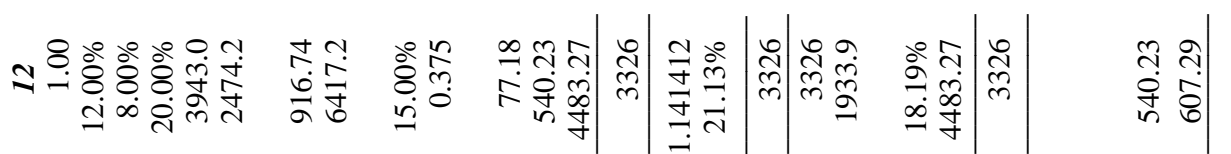

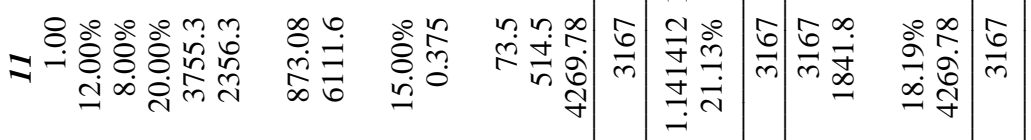

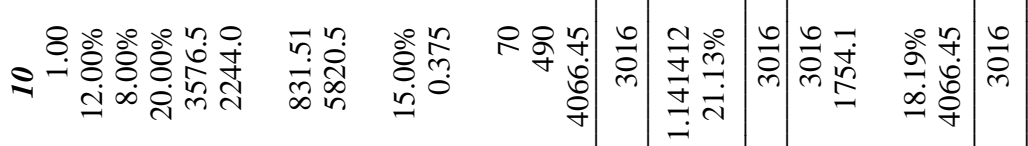

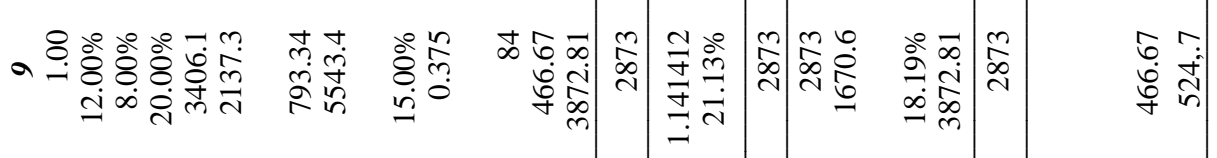

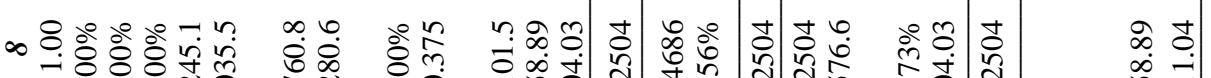

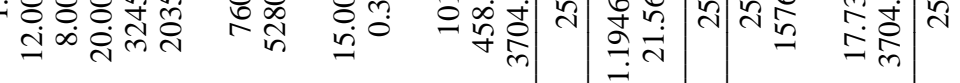

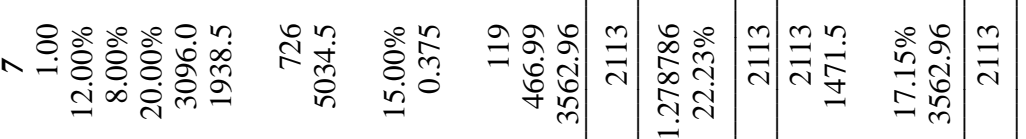

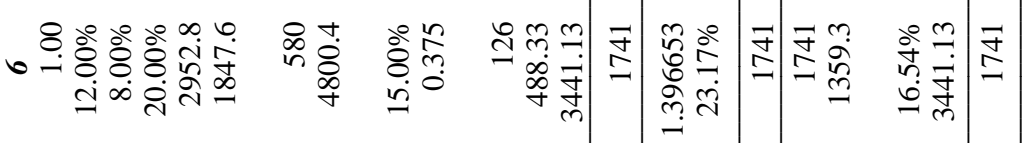

字

\&.

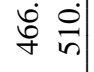

$m$ กิ

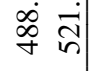

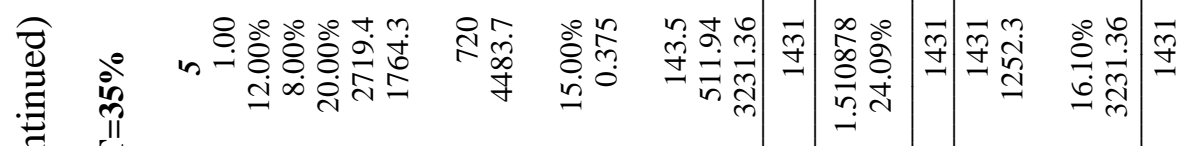

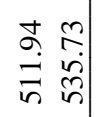

苛

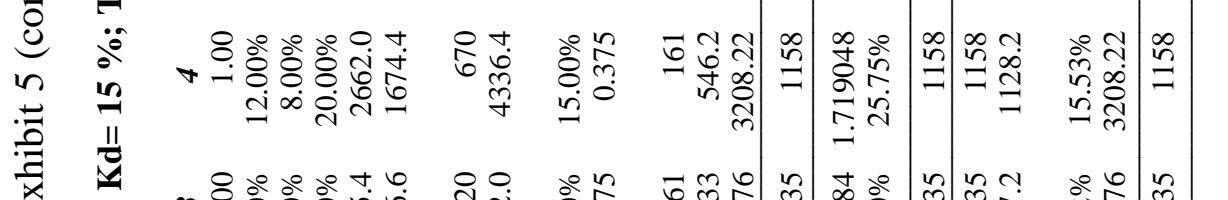

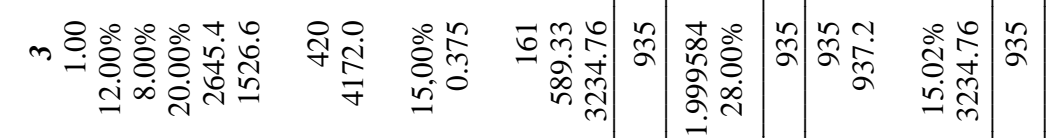

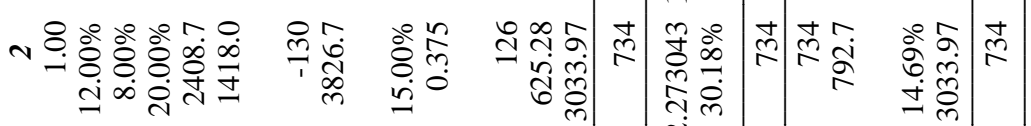

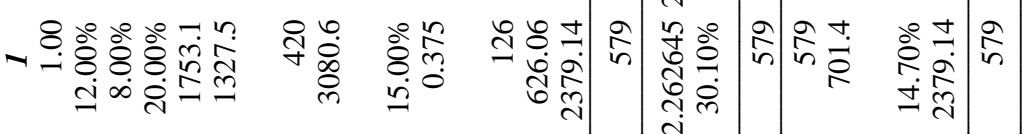

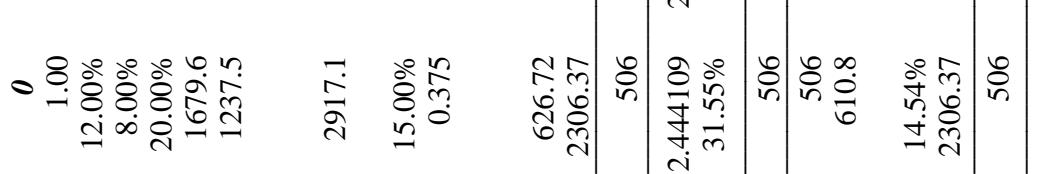
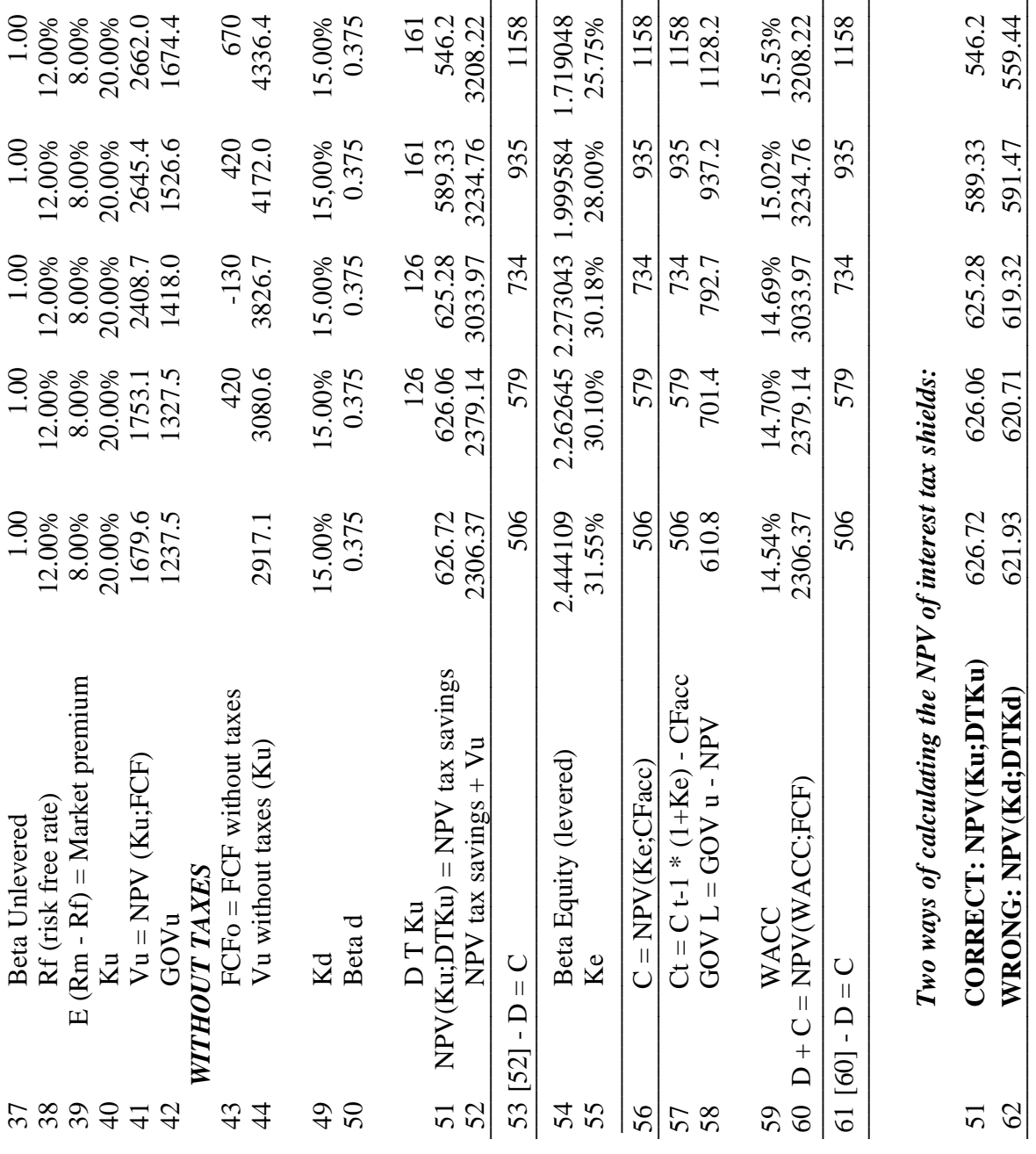

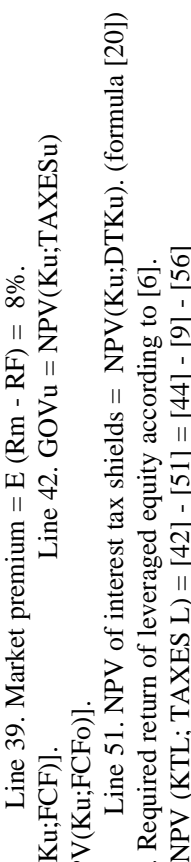



II II ${ }^{2}$ 号焉

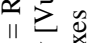

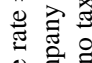

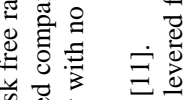

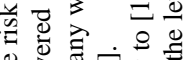

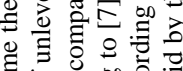

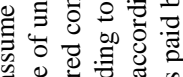

(2)

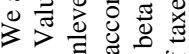

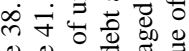

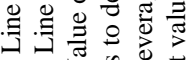

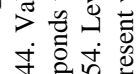

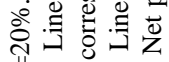

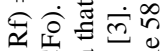

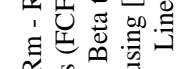

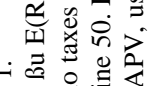

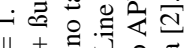

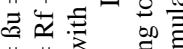

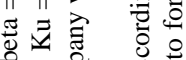

远

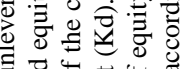

旸定

过

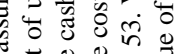

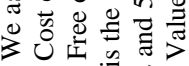

的守学守 婂






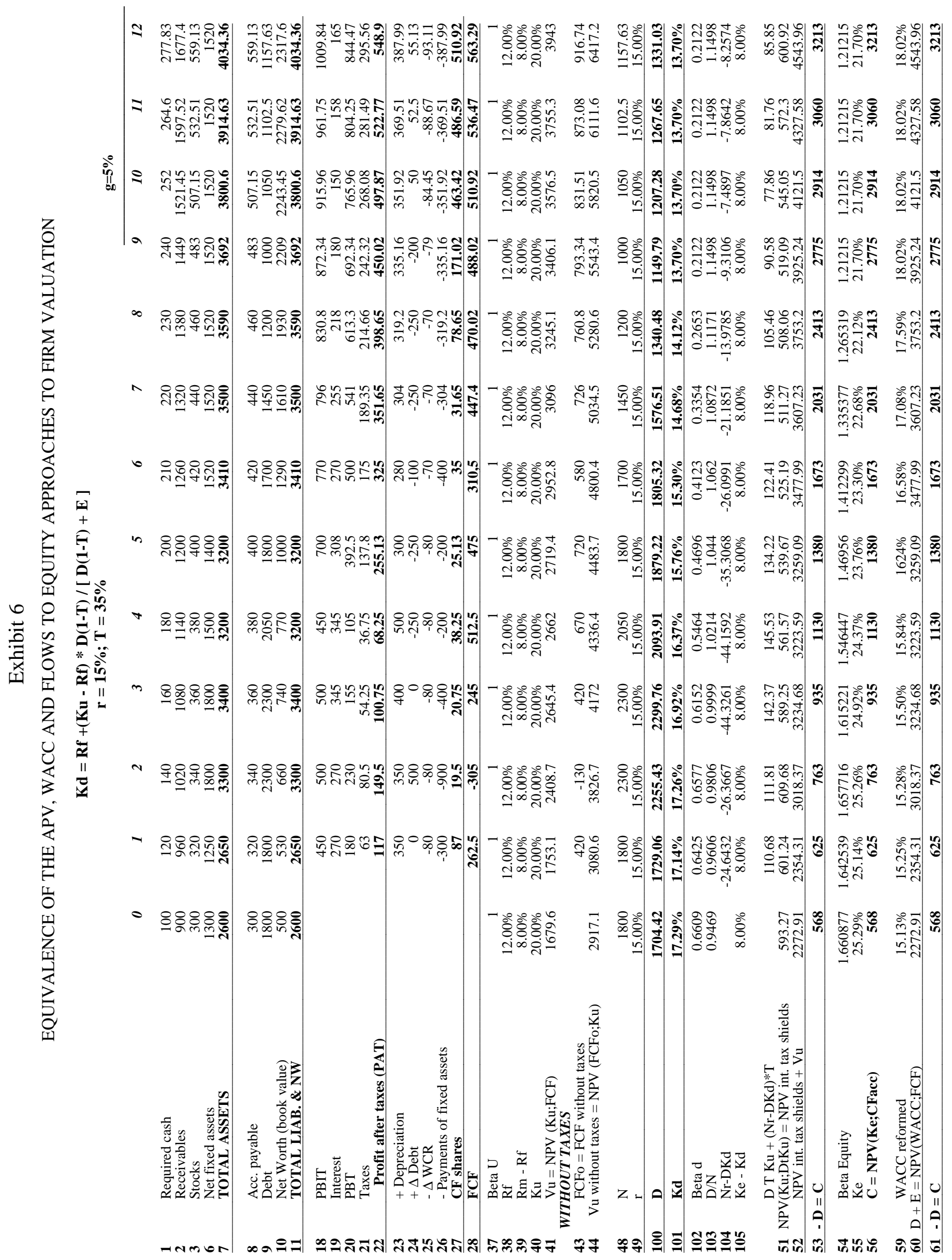




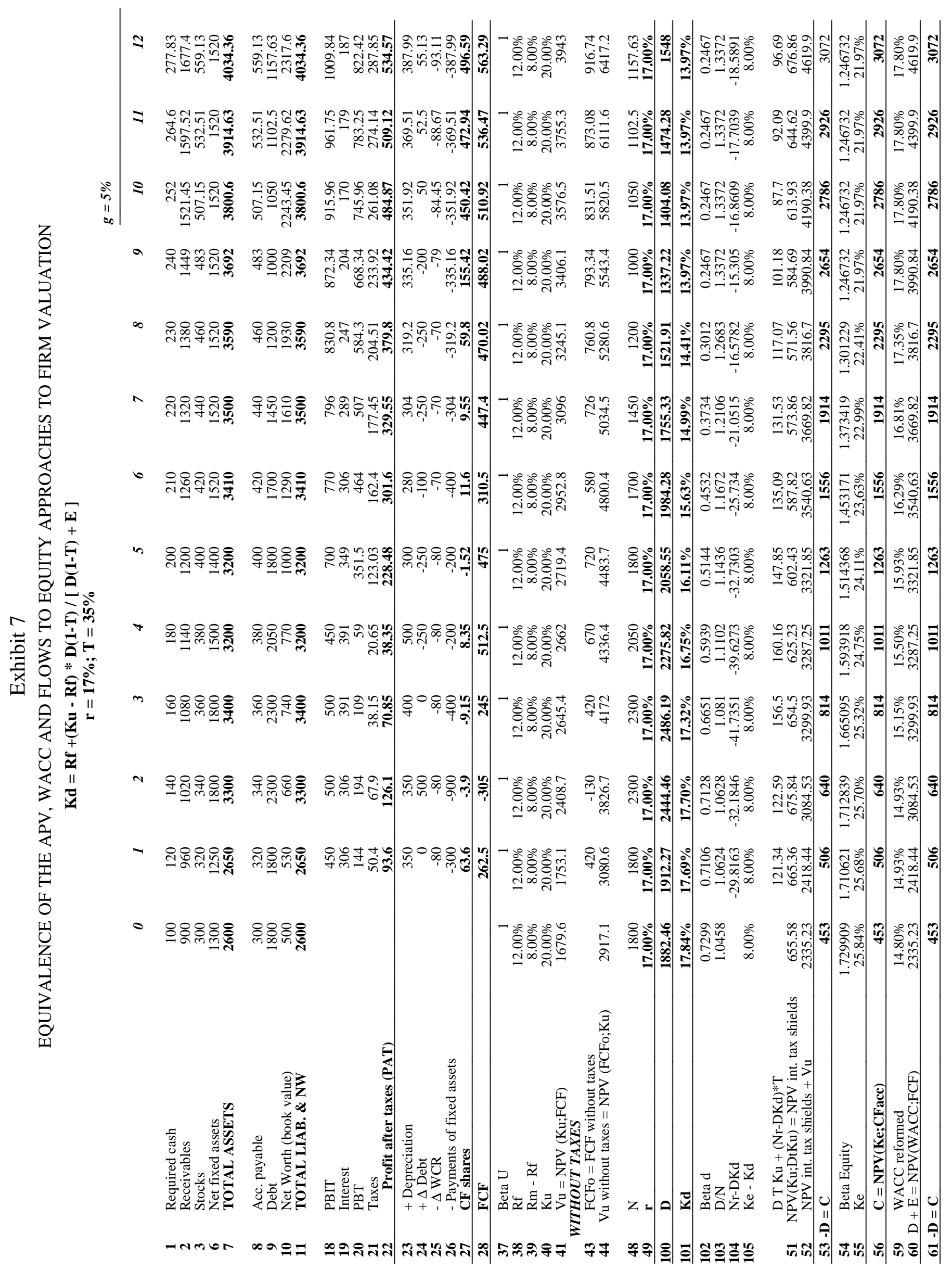




\author{
Appendix 1 \\ EQUIVALENCE OF THE APV, WACC AND FLOWS TO EQUITY APPROACHES \\ TO FIRM VALUATION
}

\title{
Alternative formula for companies with constant growth «g»
}

Many authors and professors maintain that

[24] NPV of interest tax shields $=\frac{\mathrm{DTKd}}{\mathrm{Kd}-\mathrm{g}}$

The intuition behind this formula considers that the NPV of interest tax shields is the NPV of the tax shield (DT Kd $=$ Taxes $_{U}-$ Taxes $_{L}$ ) discounted at the cost of the debt.

The first problem with this formula, as we have already said, is that it discounts a flow (DT Kd) at the debt rate, even though DT Kd is the difference of 2 flows (Taxes $_{U}$ and Taxes $_{L}$ ) with different risk.

The second problem is that the three valuation formulas (formulas [1], [2] and [3]) give different values, unless we redefine several formulas. If we want to maintain [24], and have the same value with formulas [1], [2] and [3] $\left(\mathbf{K e}_{\mathbf{w}}=\right.$ Required return of levered equity if [24] holds; $\mathbf{C}_{\mathbf{w}}=$ Value of shares at $\mathrm{t}=0$ if [24] holds), we get the following relationships:

Instead of formula [10], we get [10w]

$[10 w]$

$$
\begin{aligned}
& \mathrm{Ku}=\frac{\mathrm{Kd}\left[\mathrm{C}_{\mathrm{w}} \mathrm{Ke}_{\mathrm{w}}+\mathrm{DKd}(1-\mathrm{T})\right]-\mathrm{g}\left(\mathrm{C}_{\mathrm{w}} \mathrm{Ke}_{\mathrm{w}}+\mathrm{DKd}\right)}{\mathrm{Kd}\left[\mathrm{C}_{\mathrm{w}}+\mathrm{D}(1-\mathrm{T})\right]-\mathrm{g}\left(\mathrm{C}_{\mathrm{w}}+\mathrm{D}\right)}= \\
& =\frac{\mathrm{C}_{\mathrm{w}} \mathrm{Ke}_{\mathrm{w}}+\mathrm{DKd} \frac{[\mathrm{Kd}(1-\mathrm{T})-\mathrm{g}]}{\mathrm{Kd}-\mathrm{g}}}{\mathrm{C}_{\mathrm{w}}+\mathrm{D} \frac{[\mathrm{Kd}(1-\mathrm{T})-\mathrm{g}]}{\mathrm{Kd}-\mathrm{g}}} \\
& \mathrm{Ke}_{\mathrm{w}}=\mathrm{Ku}+\frac{\mathrm{D}}{\mathrm{C}_{\mathrm{w}}}\left[\frac{\mathrm{Kd}(1-\mathrm{T})-\mathrm{g}}{\mathrm{Kd}-\mathrm{g}}\right](\mathrm{Ku}-\mathrm{Kd})
\end{aligned}
$$

We can see that if $\mathrm{g}>\mathrm{Kd}(1-\mathrm{T})$, then $\mathrm{Ke}<\mathrm{Ku}$, which makes no sense. 


\section{Appendix 1 (continued)}

And instead of [11], we now have [11w]

[11] $\quad \beta_{U}=\beta_{L} \frac{C}{C+D(1-T)}+\beta_{D} \frac{D(1-T)}{C+D(1-T)}$

[11w] $\beta_{\mathrm{U}}=\beta_{\mathrm{LW}} \frac{\mathrm{C}_{\mathrm{w}}}{\mathrm{C}_{\mathrm{w}}+\mathrm{D}\left[\frac{\mathrm{Kd}(1-\mathrm{T})-\mathrm{g}}{\mathrm{Kd}-\mathrm{g}}\right]}+\beta_{\mathrm{LW}} \frac{\mathrm{D}\left[\frac{\mathrm{Kd}(1-\mathrm{T})-\mathrm{g}}{\mathrm{Kd}-\mathrm{g}}\right]}{\mathrm{C}_{\mathrm{w}}+\mathrm{D}\left[\frac{\mathrm{Kd}(1-\mathrm{T})-\mathrm{g}}{\mathrm{Kd}-\mathrm{g}}\right]}$

$\mathrm{C}_{\mathrm{W}}-\mathrm{C}=\mathrm{NPV}_{\mathrm{W}}-\mathrm{NPV}=\mathrm{DT}[\mathrm{Kd} /(\mathrm{Kd}-\mathrm{g})-\mathrm{Ku} /(\mathrm{Ku}-\mathrm{g})]>0$ if $\mathrm{Kd}<\mathrm{Ku}$

If $\mathrm{g}>\mathrm{Kd}(1-\mathrm{T})$, then $\mathrm{C}_{\mathrm{W}}>\mathrm{Vu}$, which is, obviously, inconsistent. 
Appendix 2

EQUIVALENCE OF THE APV, WACC AND FLOWS TO EQUITY APPROACHES TO FIRM VALUATION

Most important valuation formulas

General formulas:

[1]

$$
\mathrm{D}+\mathrm{C}=\sum_{\mathrm{t}=1}^{\infty} \frac{\mathrm{FCF}_{\mathrm{t}}}{\prod_{1}^{\mathrm{t}}\left(1+\mathrm{WACC}_{\mathrm{t}}\right)}
$$

[2] $\mathrm{C}=\sum_{\mathrm{t}=1}^{\infty} \frac{\mathrm{CFacc}_{\mathrm{t}}}{\prod_{1}^{\mathrm{t}}\left(1+\mathrm{Ke}_{\mathrm{t}}\right)}$

[3] $\mathrm{D}+\mathrm{C}=\sum_{\mathrm{t}=1}^{\infty} \frac{\mathrm{FCF}_{\mathrm{t}}}{\prod_{1}^{\mathrm{t}}\left(1+\mathrm{Ku}_{\mathrm{t}}\right)}+\mathrm{NPV}$ of interest tax shields

[4]

$$
\mathrm{D}_{0}=\sum_{\mathrm{t}=1}^{\infty} \frac{\mathrm{I}_{\mathrm{t}}+\mathrm{N}_{\mathrm{t}}}{\prod_{1}^{\mathrm{t}}\left(1+\mathrm{Kd}_{\mathrm{t}}\right)}
$$

[20] NPV OF INTEREST TAX SHIELDS $=\sum_{\mathrm{t}=1}^{\infty} \frac{\mathrm{D}_{\mathrm{t}-1} \mathrm{Ku}_{\mathrm{t}} \mathrm{T}}{\prod_{\mathrm{t}=1}^{\mathrm{t}}\left(1+\mathrm{Ku}_{\mathrm{t}}\right)}$

[5] $\mathrm{Ku}=\mathrm{R}_{\mathrm{F}}+\beta_{\mathrm{U}} \mathrm{P}_{\mathrm{M}}$

[6] $\mathrm{Ke}=\mathrm{R}_{\mathrm{F}}+{ }^{\mathrm{B}} \mathrm{L} \mathrm{P}_{\mathrm{M}}$

[7] $\mathrm{Kd}=\mathrm{R}_{\mathrm{F}}+\beta_{\mathrm{d}} \mathrm{P}_{\mathrm{M}}$

$\mathrm{K}_{\mathrm{T}_{\mathrm{U}}}=\mathrm{Ku} \quad \mathrm{KT}_{\mathrm{L}_{1}}=$ required rate for the Taxes $\mathrm{L}_{1}=\mathrm{Ku}_{1}+\mathrm{T} \mathrm{D}_{0}\left(\mathrm{Ku}_{1}-\mathrm{Kd}_{1}\right) / \mathrm{GOV}_{\mathrm{L}_{0}}$

Perpetuities without growth:

[1p] $\mathrm{C}=\mathrm{FCF} / \mathrm{WACC}-\mathrm{D} ; \quad[2 p] \mathrm{C}=\mathrm{CFacc} / \mathrm{Ke}$

[3p] $\quad \mathrm{C}=\mathrm{FCF} / \mathrm{Ku}+\mathrm{NPV}$ of interest tax shields $-\mathrm{D}$

[8] $\quad \mathrm{WACC}=\frac{\mathrm{C} \mathrm{Ke}+\mathrm{D} \mathrm{Kd}(\mathbf{1}-\mathrm{T})}{\mathrm{C}+\mathrm{D}}$
[14] $\mathrm{K}_{\mathrm{T}}=\mathrm{Ku} ; \quad \mathrm{K}_{\mathrm{TL}}=\mathrm{Ke}$

[4p] CFacc $=$ FCF $-\mathrm{I}(1-\mathrm{T})=$ FCF - D Kd $(1-\mathrm{T})$

[9] NPV of interest tax shield $=$ DT 
Appendix 2 (continued)

[10]

$$
K u=\frac{C K e+D K d(1-T)}{C+D(1-T)}
$$

[12] $\quad \mathrm{WACC}=\mathrm{Ku} \frac{\mathrm{C}+\mathrm{D}(1-\mathrm{T})}{\mathrm{C}+\mathrm{D}}=\mathrm{Ku}\left(1-\frac{\mathrm{D} T}{\mathrm{C}+\mathrm{D}}\right)$
[11]

$\beta_{\mathrm{L}}=\frac{\beta_{\mathrm{U}}[\mathrm{C}+\mathrm{D}(1-\mathrm{T})]-\beta_{\mathrm{d}} \mathrm{D}(1-\mathrm{T})}{\mathrm{C}}$

[13]

\section{Perpetuities with constant growth g:}

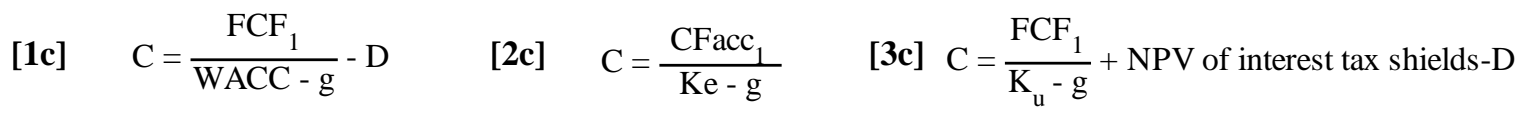

[4c] $\mathrm{CFacc}_{1}=\mathrm{FCF}_{1}-\mathrm{Do}[\mathrm{Kd}(1-\mathrm{T})-\mathrm{g}] \quad[8] \quad \mathrm{WACC}=\frac{\mathrm{C} \mathrm{Ke}+\mathrm{D} \mathrm{Kd}(1-\mathrm{T})}{\mathrm{C}+\mathrm{D}}$

[15] NPV int tax shields $=(\mathrm{C}+\mathrm{D})(\mathrm{Ku}-\mathrm{WACC}) /(\mathrm{Ku}-\mathrm{g}) \quad[1 \mathbf{1 6}] \mathrm{NPV}$ int tax shields $=\mathrm{DT} \mathrm{Ku} /(\mathrm{Ku}-\mathrm{g})$

$$
\mathrm{K}_{\mathrm{T}_{\mathrm{L}}}-\mathrm{g}=\frac{\mathrm{CKe}-\mathrm{g}(\mathrm{C}+\mathrm{D})+\mathrm{H}}{\mathrm{CKu}-\mathrm{g}(\mathrm{C}+\mathrm{D})+\mathrm{H}}(\mathrm{Ku}-\mathrm{g})
$$

$$
\mathrm{C}=\frac{\mathrm{CFacc}}{\mathrm{Ku}-\mathrm{g}}-\frac{\mathrm{D}(\mathrm{Ku}-\mathrm{Kd})(1-\mathrm{T})}{\mathrm{Ku}-\mathrm{g}}
$$

Perpetuities when $\mathbf{r} \neq \mathrm{Kd} . \quad \mathrm{D}=\mathrm{Nr} / \mathrm{Kd}$.

Companies with constant growth when $\mathbf{r} \neq \mathrm{Kd}$.

[4'c'] CFacc $=$ FCF $-\mathrm{Nr}(1-\mathrm{T})+\mathrm{gN}=\mathrm{FCF}-\mathrm{D}(\mathrm{Kd}-\mathrm{g})+\mathrm{NrT}$

$\left[8^{\prime}\right] \quad$ WACC $=\frac{\mathrm{C} \mathrm{Ke}+\mathrm{D} \mathrm{Kd}-\mathrm{Nr} \mathrm{T}}{\mathrm{C}+\mathrm{D}}$

[16"] NPV of interest tax shields $=\frac{\mathrm{DTKu}}{\mathrm{Ku}-\mathrm{g}}-\frac{\operatorname{Tg}(\mathrm{D}-\mathrm{N})}{\mathrm{Ku}-\mathrm{g}}$
A formula for Kd
[21] $K d=R_{F}+\frac{D(1-T)}{D(1-T)+C}\left(K u-R_{F}\right)$
[22] $\beta_{\mathrm{d}}=\frac{\mathrm{D}(1-\mathrm{T})}{\mathrm{D}(1-\mathrm{T})+\mathrm{C}} \beta_{\mathrm{U}}$ 


\section{Bibliography}

Ashton, D.J. and D.R. Atking, «Interactions in Corporate Financing and Investment Decisions: A Further Comment», Journal of Finance (December 1978) pp. 1447-1453.

Brealey, R.A. and S.C. Myers, «Principles of Corporate Finance», New York, McGraw-Hill, 4th edition, 1991.

Chambers, D.R., R.S. Harris, and J.J. Pringle, «Treatment of Financing Mix Analyzing Investment Opportunities», Financial Management (Summer 1982), pp. 24-41.

Conine, T.E.Jr., «Corporate Debt and Corporate Taxes: An Extension», Journal of Finance (September 1980), pp. 1033-1037.

DeAngelo, L. «Equity valuation and Corporate Control», The Accounting Review 65, 1990, pp. 93-112.

Denis, D. and D. Denis, «Managerial Discretion, Organizational Structure, and Corporate performance: A Study of Leveraged Recapitalizations», Journal of Accounting and Economics 16, 1993, pp. 209-236.

Ezzell, J.R. Jr. «An APV Analysis of Capital Budgeting Under Inflation», Financial Management (Autumn 1984) p.. 49-54.

Fama, E. «Risk-Adjusted Discount Rates and Capital Budgeting Under Uncertainty», Journal of Financial Economics (August 1977), pp. 3-24.

Hamada and Myron S. Scholes, «Taxes and Corporate Financial Management», in Recent Advances in Corporate Finance, E.I. Alman and M.G. Subrahmanyam (eds.), Homewood, IL. Richard D. Irwin, 1985.

Harris, R.S. and J.J. Pringle, «Risk-Adjusted Discount Rates Extensions from the Average-Risk Case», Journal of Financial Research (Fall 1985), pp. 237-244.

Inselbag, I. and H. Kaufold, «How to Value Recapitalizations and Leveraged Buyouts», Continental Bank Journal of Applied Corporate Finance (Summer 1989), pp. 87-96.

Inselbag, I. and H. Kaufold, «A Comparison of Alternative Discounted Cash Flow Approaches to Firm Valuation», Working Paper, Wharton School, June 1990.

Kaplan, S. «The Effects of Management Buyouts on Operations and Value», Journal of Financial Economics 24, 1989, pp. 217-254.

Kaplan, S. and J. Sterin, «How Risky is the Debt in Highly Leveraged Transactions?», Journal of Financial Economics 27, 1990, 215-246.

Lewellen, W.G. and D.R. Emery, «Corporate Debt Management and the Value of the Firm», Journal of Financial Quantitative Analysis (December 1986), pp. 415-426.

Luehrman, T. and L. Hirt, «Highly Levered Transactions and Fraudulent Conveyance Law», Working paper, Harvard Business School, Boston, MA, 1991.

Masulis, R.W., «The Impact of Capital Structure Change on Firm Value: Some Estimates», Journal of Finance (March 1983), pp. 107-126.

Miles, J. and J.R. Ezzell, «The Weighted Average Cost of Capital, Perfect Capital Markets and Project Life: A Clarification», Journal of Financial and Quantitative Analysis (September 1980), pp. 719-730.

Miles, J. and J.R. Ezzell, «Reformulating Tax Shield Valuation: A Note», Journal of Finance (December 1985), pp. 1485-1492.

Miller, M.H., «Debt and Taxes», Journal of Finance (May 1977), pp. 261-276.

Modigliani, F and M.H. Miller, «Corporate Income Taxes and the Cost of Capital: A Correction», American Economic Review (June 1963), pp. 433-443.

Myers, S.C., «Interactions of Corporate Financing and Investment Decisions - Implications for Capital Budgeting», Journal of Finance (March 1974), pp. 1-25.

Myers, S.C. and R.S. Ruback, «Discounting Rules for Risky Assets», Harvard Business School Working Paper, November 1988.

Myers, S.C. and S.M. Turnbull, «Capital Budgeting and the Capital Asset Pricing Model: Good News and Bad News», Journal of Finance (May 1977), pp. 321-332.

Ruback, R.S. «Calculating the Market Value of Risk-Free Cash Flows», Journal of Financial Economics (March 1986), pp. 323-339.

Rubinstein, M.E. «A Mean-Variance Synthesis of Corporate Financial Theory», Journal of Finance (March 1973), pp. 167-182.

Sick, G.A. «Tax-Adjusted Discount Rates», Management Science (December 1990), pp. 1432-1450.

Sick, G.A. «A Certainty-Equivalent Approach to Capital Budgeting», Financial Management (Winter 1986), pp. 23-32.

Stevens, R. «New Methods in testing Asset Pricing Models», Working paper, University of Chicago, Chicago, IL, 1993.

Taggart, R.A. Jr. «Capital Budgeting and the Financing Decision: An Exposition», Financial Management (Summer 1977), pp. 59-64.

Taggart, R.A. Jr. «Consistent Valuation and Cost of Capital. Expressions With Corporate and Personal Taxes», Financial Management (Autumn 1991), pp. 8-20. 
IESE

DOCUMENTOS DE INVESTIGACION - RESEARCH PAPERS

No. TITULO

AUTOR

D/ 274 Investing in Russia.

July 1994, 36 Pages

Taylor G.

D/ 275 Aspectos éticos en la consultoría de búsqueda de directivos. Septiembre 1994, 16 Págs.

Melé D.

Roig B.

D/ 276 Factores determinantes del ahorro.

Septiembre 1994, 88 Págs.

Argandoña A.

D/ 277 Spain and the European social charter.

September 1994, 33 Pages

Argandoña A.

D/ 278 Technology management in Spain.

October 1994, 14 Pages

Riverola J.

Muñoz-Seca B.

D/ 279 Códigos de conducta empresarial: ¿Pueden contribuir al desarrollo ético de los empleados?

Octubre 1994, 14 Págs.

Melé D.

D/ 280 Las relaciones laborales en Italia.

Noviembre 1994, 61 Págs.

Gómez S.

Pons M.

D/ 281 Training the next generation of owners and managers: A possible

Tomaselli S. key role for directors in family businesses.

November 1994, 17 Pages

D/ 282 Los servicios: El binomio privatización- desregulación. El caso de la educación.

Argandoña A.

Diciembre 1994, 15 Págs.

D/ 283 Las relaciones laborales en el Reino Unido.

Diciembre 1994, 75 Págs.

Gómez S.

Pons $\mathrm{M}^{\mathrm{a}}$ 
IESE

DOCUMENTOS DE INVESTIGACION - RESEARCH PAPERS

No. TITULO

AUTOR

D/ 284 Isomorphic pressures on identity: The case of learning partnerships with business schools.

December 1994, 21 Pages

Enrione A.

Knief C.

Mazza C.

D/ 285 Control and incentives in organizational design.

January 1995, 22 Pages

Ricart J.E.

Rosanas J.M.

D/ 286 Asset-based competition and industry structure:

Recapturing the early concepts of strategic groups.

Enrione A.

January 1995, 29 Pages

García Pont C.

D/ 287 Finanzas en empresas familiares.

Vilaseca A.

Enero 1995, 19 Págs.

D/ 287 Finance in Family Business.

BIS April 1995, 21 Pages

Vilaseca A.

D/ 288 Networks versus bureaucracies: The dilemmas of organizations of the future.

Alvarez J.L. January 1995, 41 Pages

Ferreira M.A.

D/ 289 Consorcios de exportación enfocados: El diseño y puesta en

Renart L.G. práctica.

Febrero 1995, 43 Págs.

D/ 290 La continuidad de las empresas familiares.

Marzo 1995, 78 Págs.

Gallo M.A.

Cappuyns K.

Estapé M.J.

D/ 290 Continuity of family businesses.

Gallo M.A.

BIS March 1995, 76Pages

Cappuyns K.

Estapé M.J.

D/ 291 Indebtedness: Ethical problems.

Argandoña A. March 1995, 17 Pages 